\title{
Irrigation Scheduling under High Efficiency (Pressurized) Irrigation Systems
}

\section{Mumtaz Awan ${ }^{1}$, Shehzad Ahmad², Ali Ajaz ${ }^{3}$}

1- Project Agronomist, National Engineering Services Pakistan (NESPAK)

2- Design Engineer, National Engineering Services Pakistan (NESPAK)

3- Assistant Design Engineer, National Engineering Services Pakistan (NESPAK)

Document type: Technical Report

Publisher:

Project-Implementation Supervision Consultants (PSC) - A Joint Venture of National Engineering Services Pakistan (NESPAK) and National Development Consultants (NDC)

Document Number: N/A

Month Published: February, 2014

DOI: 10.13140/RG.2.2.36209.38249/1

\section{IRRIGATION SCHEDULING UNDER \\ HIGH EFFICIENCY (PRESSURIZED) IRRIGATION SYSTEMS}

FOR DRIP AND SPRINKLER IRRIGATION UNITS

\begin{abstract}
Technical Team
\end{abstract}
Mumtaz Awan

Project Agronomist

Shehzad Ahmad

Design Engineer (HEIS)

Ali Ajaz

Assistant Design Engineer (HEIS)

Principal Editor

\section{SEE NEXT PAGE}

February 2014,

Lahore, Pakistan

Project- Implementation Supervision Consultants (PSC)

A Joint Venture of NESPAK and NDC 


\section{IRRIGATION SCHEDULING UNDER HIGH EFFICIENCY (PRESSURIZED) IRRIGATION SYSTEMS}

FOR DRIP AND SPRINKLER IRRIGATION UNITS

Technical Team

Mumtaz Awan

Project Agronomist

Ali Ajaz

Assistant Design Engineer (HEIS)

\section{Principal Editor}

Project Manager
Shehzad Ahmad

Design Engineer (HEIS)

$$
\begin{aligned}
& \text { Project- Implementation Supervision Consultants (PSC) } \\
& \text { A Joint Venture of NESPAK and NDC }
\end{aligned}
$$




\section{IRRIGATION SCHEDULING UNDER HEIS}

TABLE OF CONTENTS

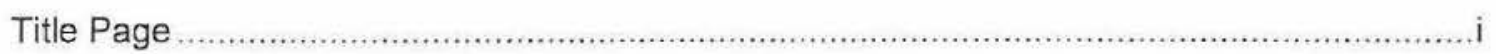

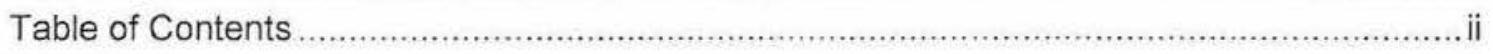

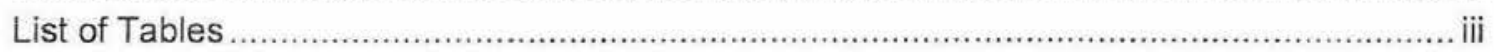

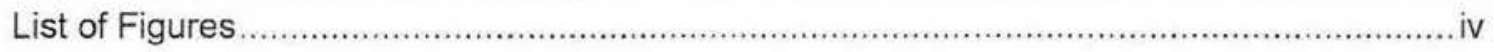

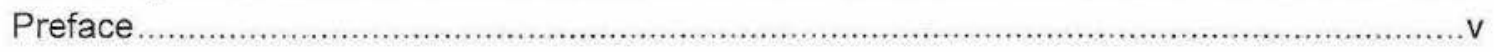

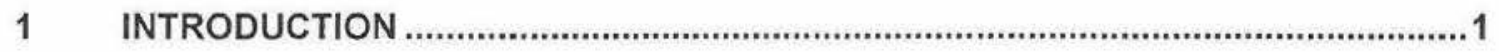

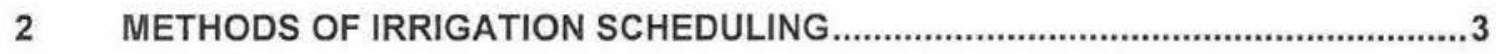

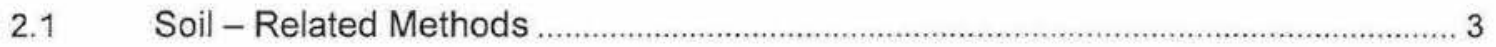

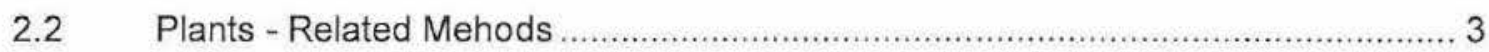

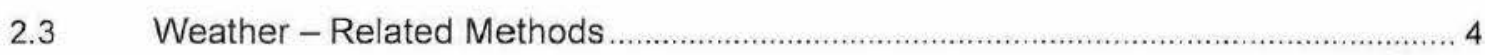

3 STEPS FOR PREPARATION OF IRRIGATION SCHEDULE....................................5

3.1 Calculation of Daily Crop Water Requirements (CWR) …..................................... 5

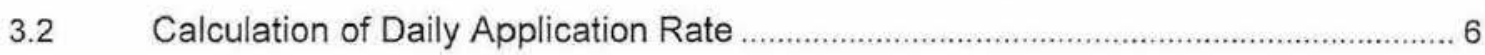

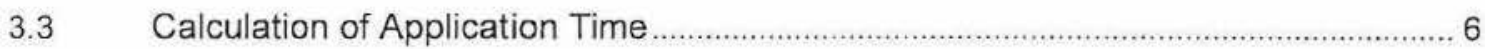

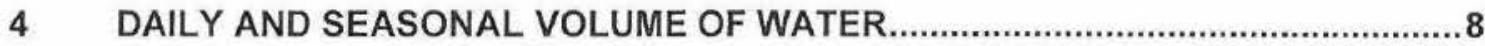




\section{LIST OF TABLES}

Table - 1. Basic Data Sheet for Preparation of Irrigation Schedule

Table - 2. Reference Evapotranspiration of all Districts of Punjab

Table - 3. Duration of Growth Stages and $K_{c}$ Value of Agronomic Crops

Table - 4. Duration of Growth Stages and $K_{c}$ Values of Vegetables Crops

Table - 5. Duration of Growth Stages and $K_{c}$ Values of Fruit Crops

Table - 6. Sample Sheet for Preparation of Irrigation Schedule

Table -7 . Irrigation Schedule for Cotton Crop

Table - 8 Irrigation Schedule for Sugarcane Crop

Table - 9. Irrigation Schedule for Maize Crop

Table - 10. Irrigation Schedule for Wheat Crop

Table - 11. Irrigation Schedule for Citrus Crop

Table - 12. Irrigation Schedule for Peas Crop 


\section{LIST OF FIGURES}

Figure - 1. Crop Growth Stage Coefficient (Kc) Curve for Cotton

Figure - 2. Crop Growth Stage Coefficient $(K c)$ Curve for Sugarcane

Figure - 3. Crop Growth Stage Coefficient (Kc) Curve for Maize

Figure - 4. Crop Growth Stage Coefficient $(\mathrm{Kc})$ Curve for Wheat

Figure -5 . Crop Growth Stage Coefficient $(K c)$ Curve for Citrus

Figure - 6. Crop Growth Stage Coefficient (Kc) Curve for Peas 


\section{PREFACE}

This is, indeed, highly gratifying to observe that high efficiency irrigation systems have established their worth with the farming community in Punjab and their acceptance is accelerating on day to day basis. The benefits of these HEISs have been experienced pragmatically by the beneficiaries and their interviews reveal that substantial savings in water, fertilizers, pesticides specially the weedicides, energy and labor have been realized on most of the same. As a result extensive installation of drip and sprinkler irrigation systems under s in progress which, indeed, is helping in combating with shortage of irrigation water in the country on one hand and is proving effective in bringing the yield levels of crops of the country at par with the world standards on the other. Their affectivity, however, largely depends upon accurate scheduling of irrigation through the same and a definite rise in their efficiency may be accrued through proper monitoring of the schedules both with respect to their preparation as well as their implementation.

Since HEISs are relatively a new intervention in Pakistan, there exists a dearth of relevant printed material regarding various operational aspects of the systems especially in relation to preparation of fertigation, irrigation and chemigation schedules. Perhaps, the most critical and the most wanted facet of these newly introduced systems is the preparation of proper irrigation schedules for various crops being grown in their command. In addition, the training of project staff and the users of the systems regarding these schedules covering their understanding and implementation in the field appears to be a missing link. A fair analysis of the factors leading to such gaps reflects that lack of technical material on the subject is the primary reason

The effort made by PSC in the form of this manual is expected to serve the purpose in question. Solved examples of preparation of schedules for a number of crops have been added to give an in depth orientation to the reader. Through requisite review of this manual, it will not only be possible to check and monitor the irrigation schedules supplied on some of the sites by the SSCs for their authenticity and accuracy but it will also enable the project staff especially the HEIS teams to prepare and provide the same at the farms/sites without these schedules on instant basis. 


\section{INTRODUCTION}

Improvement in crop production cannot be ascertained without adoption of advanced management practices. If all the inputs required for improved yields are managed on the basis of latest economic principles and focus is made on taking up the entire agricultural enterprise on commercial footings, it may be firmly envisaged that a production level at par with the international standards may be achieved without any qualm and apprehension. Handsome research has been carried out regarding each input and clues have been determined which have brought significant developments in the area of desired objectives. Irrigation is one of the major inputs which like other ones, has attracted considerable attention of the researchers. Resultantly, highly effective and comprehensive aspects of this input have been unveiled especially with reference to soil-plant-water-atmosphere relationships.

An advanced method of irrigation must ensure that there is neither over irrigation which brings the soil often to saturation point completely eliminating the oxygen from the root zone nor under irrigation which often renders the soil moisture down to a level where ionic absorption of nutrients is impeded. Both of these physiological stresses adversely affect the plant growth and drag it to a position where in the reduction in yield below its potential becomes a natural end result. High Efficiency Irrigation Systems, especially the drip irrigation, have made this breakthrough and have proven to be the ideal methods. In addition to protecting the plants from any physiological stress, these help in ample saving of energy, economize labor, facilitate optimum application of nutrients and significantly reduce the incidence of weeds infestation. These have, virtually, made it possible to apply correct amount of water to the plants at exact time. Accordingly, the crop does not face any shortage of water or air or nutrients throughout its period of growth and this helps in hitting the potential both in yield as well as quality of production. This is, however, to be kept in view that the efficiency of HEISs depends primarily upon appropriate irrigation scheduling. If the time of application of water does not synchronize with the crop water requirement in exact accordance, certainly the efficiency of the system will go to adverse. In case the application time is higher than the requirement, both irrigation water and the energy will be wasted and in case the irrigation has been scheduled for a time span lesser than the requirement, it will result in reduction of the yield and wastage of resources. It is, therefore, highly important that after installation of the HEISs, not only their apposite irrigation schedules are prepared but the same are implemented with extreme care also so that the desired and expected benefits of these systems may be accrued in letter and spirit.

Irrigation Scheduling deals with application of irrigation water to a crop at the right time in the right amount. In other words, it focuses upon when to irrigate a crop and how much water to apply during each irrigation. The significance of this parameter of crop production is revealed from the fact that full potential of any crop cannot be hit unless scheduling of irrigation water is made in such a way that the crop never faces its shortage throughout its period of growth. Under conditions of low water availability, not only the absorption or ionic uptake of nutrients is held back but many other physiological processes in the plant cells get impeded also which ultimately lead to low yields. Contrarily, over irrigation proves detrimental in a number of ways 
as it blocks the availability of oxygen to the roots, it leads to leaching of valuable nutrients down to the zone below root level and results in wastage of water as well energy.

It, therefore, becomes vital that irrigation of a crop is managed in such a way that an optimum moisture level is maintained in the root zone to effectively fulfill the needs of the plants throughout the period of their demand and this is possible only through proper irrigation scheduling. 


\section{METHODS OF IRRIGATION SCHEDULING}

Several methods have been devised by the irrigation experts to determine proper time of applying irrigation to a crop and estimating the volume of water to be applied at each irrigation. All of these can be categorized in three broad groups.

\subsection{Soil - related Methods}

This group includes approaches through which the soil contents are estimated in terms of percentage of water or in terms of tension for moisture that is existing in the soil compared to the level of moisture at its field capacity and the irrigations are scheduled on the bases of this percentage or tension. Methods such as Feel and Appearance, Gravimeteric measurement, Use of Gypsum Blocks, Use of Tensiometers, Gamma Rays attenuation and Use of Neutron Probe have been referred very often. All of these methods need establishment of a correlation with respect to plant water use for scheduling irrigations and all have certain merits and demerits concerning particularly the accuracy of results, difficulty in use and cost effectiveness.

A general assumption or principle is kept in view while scheduling irrigations through soil related methods. It has been realized on the basis of research observations that plants can easily absorb water from soil so far it is above $50 \%$ of its field capacity. In clayey soils, this limit is considered better if fixed as $60 \%$ as these soils hold the moisture more tightly compared to other soils, for loamy soils, this should be $50 \%$ and in case of sands, one go even up to $40 \%$ although the water holding capacity of sandy soils is the least i.e. almost $1 / 3$ of the capacity of clays. The frequency of irrigations, however, will be higher in case of sandy soils. The units often used for expressing the level of tension are bars or atmospheres.

\subsection{Plants - Related Methods}

The criterion used in this category of methods is the same as above i.e. moisture contents of the plant parts or in case of deficiency the moisture stress in the plant parts. The symptoms reflected by the plants or direct measurements of the moisture contents are made as base for deciding the time to irrigate. As per opinion of the most of the professionals, plants related methods may be considered as most dependable as the same reflect an integration of all the factors contributing/leading towards making an appropriate decision for scheduling of irrigations. Irrigation scheduling through Plant Appearance, Measurement of transpiration through Stem Flow, Measurement of water tension through Pressure Chamber, Measurement of Trunk Diameter Fluctuations, and Measurement of Leaf Transpiration through Porometer and Measurement of Canopy Temperature through Infrared Thermometry are the methods falling under this category. 


\subsection{Weather-Related Methods}

The amount of water used by the plant for its growth and development normally referred as consumptive use or evapotranspiration has been observed to be a function of weather parameters including radiation, temperature, humidity and wind velocity. The value of crop evapotranspiration is denoted by $E T_{c}$ and is determined with the help of reference evapotranspiration $\left(E T_{0}\right)$ and the ratio of evapotranspiration of any crop at a particular stage of growth to that of reference crop referred as crop coefficient $\left(K_{c}\right)$. This approach has become highly popular because of its accuracy and practicability. The values of ETo for various locations have been determined by the experts through direct, indirect and empirical methods. Recently, a panel of experts of FAO has recommended Penman Monteith equation as a method to determine $E T_{0}$ values which is now being used world over. Similarly, the values of $K_{c}$ have also been determined by the respective experts for wide spread locations. The use of evaporation pans has been considered an easy way of determining consumptive use of crops by many researchers but the approach of determining $E T_{c}$ through multiplication of $E T_{0}$ with $\mathrm{K}_{\mathrm{c}}$ has proven its worth being the most accurate and has, therefore, achieved a universal acceptance.

The method/approach mentioned the last has been adopted for preparation of irrigation schedules for crops being grown under HEISs and is discussed hereunder with respect to its application in the field.

To prepare an irrigation schedule of a crop, the information is collected and processed with the help of four documents: one Basic Data Sheet to record all particulars pertaining to the Farm, Crop and the system, two - the Table reflecting values of reference evapotranspiration

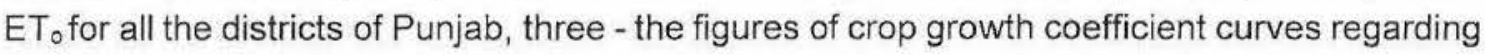
main crops to ascertain the weekly, decadal or monthly change in the values of $\mathrm{K}_{\mathrm{c}}$ factor and four - the Irrigation Schedule Calculation Sheet along with the formulae to process and develop required information necessary to reach the objective.

Basic Data Sheet is given as Table 1, the values of ETo for all districts of Punjab as Table 2, the values of Crop Growth Stage Coefficient for different agronomic crops as Table 3, of vegetable crops as Table 4 and of orchards as Table 5. In addition, a sample blank excel sheet to prepare an Irrigation Schedule has been given as Table 6. Moreover, worked examples for prepared irrigation schedules for Cotton, Sugarcane, Maize, Wheat, Citrus and Peas have also been added as Tables $7,8,9,10,11$ and 12 respectively. The soft copy of Tables 6-12 is attached in the form of compact disc.

Project - Implementation Supervision Consultants (PSC) 


\section{STEPS FOR PREPARATION OF IRRIGATION SCHEDULE}

The preparation of an Irrigation schedule is completed through following three steps:

1. Calculation of Daily Crop Water Requirement (CWR)

2. Calculation of Application Rate and

3. Calculation of Application Time.

The same are discussed as in details below:

\subsection{Calculation of Daily Crop Water Requirements (CWR)}

i. Refer to Basic Data Sheet (Table 1) and fill the basic data regarding all the required particulars.

ii. Refer to Irrigation Schedule Preparation Sheet (Table 6) and enter the months in column (a), decade number of the month in column (b) \& decade number of the crop in column (c) with effect from the date of sowing of crop indicating the number of crop days for the months, decades or weeks of crop duration in column (d).

It should be kept in mind that we are calculating Daily CWR (crop water requirement) for a particular week or decade because of progressive change in $\mathrm{Kc}$ value during every following week or decade. Some professionals take the $\mathrm{Kc}$ values on monthly basis and prepare the irrigation schedules. It is correct but comparatively less accurate than the schedules prepared on the basis of weekly or ten days values of $\mathrm{Kc}$. These are, however, workable for orchards but not desirable for agronomic and vegetable crops. On the other hand, irrigation schedule may be prepared on daily basis also, if desired. This schedule will incorporate the changes in $\mathrm{K}_{\mathrm{c}}$ values on day to day basis and will rank as the most accurate schedule.

iii. Refer to Table-2 indicating ETo values for all the months for various districts of Punjab, record corresponding ET。 value for each month, decade or week in column (e).

iv. Refer to Tables 3,4 and 5 reflecting Kc values of growth stages during a crop season. Ascertain the Kc value for each week, decade or month and record it on the IS Preparation sheet against the corresponding week, decade or month in column (f). The weekly or decadal values can best be picked through crop growth coefficient curves. The same are given as Figures 1-5 for crops mentioned above. 
v. Record the values of Canopy Factor for each week, decade or month similar to above in column $(\mathrm{g})$ through fair assessment of ground coverage by the crop as per its corresponding stage.

vi. Multiply $E T_{0}$ value of each week, decade or month with the related $\mathrm{K}_{\mathrm{c}}$ value and canopy factor to get the value of Daily Basic CWR for that week, decade or month and enter it in column (h).

vii. Divide the basic CWR with efficiency factor to determine Daily Gross CWR for that week, decade or month and enter in column (i).

viii. Subtract the amount of moisture contributed by soil, rainfall or ground water table reflecting in column (j) from the daily gross CWR and this will give us the daily net CWR of that crop. Enter this value in column (k).

\subsection{Calculation of Daily Application Rate}

a) The time in which a specific crop water requirement can be fulfilled depends on two factors: the amount of water being diverted or applied to a field per unit time also termed as "Flow Rate". Higher is the amount of flow, lesser will be the time required to fill the root zone.

b) the size of the field or zone being irrigated i.e. bigger is the field, longer will be the time required to complete the irrigation. Both of these factors have been put together in the term "Application Rate" which may be defined as the amount of water being applied to a unit piece of land in a unit time. The units for flow rate used commonly are "Liters per second (lps), Liters per hour ( $(\mathrm{pH})$, Cubic meters per hour $\left(\mathrm{m}^{3} / \mathrm{h}\right)$ and the units for area used commonly are "Square meters $\left(\mathrm{m}^{2}\right)$ and Hectares $(\mathrm{Ha})$ ". If the flow rate is in liters per hour (usual discharge/flow rate of emitters) and the area is in $\mathrm{m}^{2}$, the unit for Application Rate is " $\mathrm{mm} /$ hour". Its simple mathematical relationship is given as under:

Application Rate $(\mathrm{mm} / \mathrm{hr})=$ Flow Rate in Liters per Hour $/$ Area in $\mathrm{m}^{2}$

If the system flow rate is taken in cubic meters $\left(\mathrm{m}^{3}\right)$ per hour and the area is taken in hectares, then:

Application Rate $(\mathrm{mm} / \mathrm{hr})=\mathrm{SFR}\left(\mathrm{m}^{3}\right)^{*} 0.1 /$ Area $(\mathrm{Ha})$

Calculate application rate separately and enter it in column (I) of the Irrigation Scheme (IS) Preparation Sheet.

\subsection{Calculation of Application Time}

It is the time required to complete the CWR of a field or zone. The application rate has already been calculated. Application Time can be calculated by dividing the CWR of a day by the application rate. The formula is: 


\section{Application Time (hours) $=$ CWR $(\mathrm{mm} /$ day $) /$ Application Rate $(\mathrm{mm} / \mathrm{hr})$}

In this way, one can calculate the time of application for all the weeks or decades or even months as per assessment period of daily CWR.

With the help of formula given above, determine the values of application time in hours entering it in column $(\mathrm{m})$. Multiply these values with the number of minutes in an hour to get the values of application time in minutes and enter the same in column (n).

To calculate the time required to irrigate all the zones, multiply the time value for one zone with the number of zones highlighting the figure in column (o). 


\section{Daily and Seasonal Volume of Water}

For additional facilitation of the professionals, a column titled "Volume of Water Required" has been added. Though it does not have direct relationship with irrigation scheduling, an estimate of the amount of water required for a particular day may help the farmer in timely planning and ensuring the availability of requisite amount of water in the storage tank in case it is short. The amount of water required may be calculated as under:

$$
\text { Volume of Water/Day }\left(\mathrm{m}^{3}\right)=\text { System Flow Rate }\left(\mathrm{m}^{3}\right) \text { * Irrigation Time/Day }(\mathrm{hr})
$$

For seasonal estimate of the volume of water required by the crop, the daily values of volume will be multiplied with the requisite number of crop days to obtain the volume required in a week or decade and this value should be entered in column ( $p)$. A total of these decadal values will give us the seasonal water requirement/volume for that crop.

In addition, this value helps in comparing the volume of water applied under drip irrigation with the volume of water needed under surface irrigation. Certainly, a considerable volume of water applied under surface irrigation goes waste because of its absorption in areas out of the root zone and its evaporation up in the atmosphere without any use to the crop. The devastation of energy is another overwhelming loss. These losses contribute in lowering the efficiency of the surface irrigation system sometimes down to $50 \%$. This comparison may help the farmers in extra planning in relation to their irrigation system and thus saving not only the precious water resource but also the valuable energy from wastage.

The volume water consumed in surface irrigation of a crop can be calculated as under:-

The example is taken of the citrus orchard with its irrigation schedule given in table 10 . The area of the orchard is 15 acres, discharge at the farm is 1.5 cusecs, time required for irrigation of one acre is 2 hours and the number of irrigations in one year is 20 .

Discharge in surface irrigation $=1.5$ cusecs $=42 \mathrm{lps}=151.2 \mathrm{~m} 3 / \mathrm{hr}$

Time for one irrigation $=2 \mathrm{hr}$

Volume for one irrigation $=151.2 * 2$ (hours) $=302.4 \mathrm{~m} 3$ per acre

Volume for 15 acres irrigation $=302.4 * 15=4536 \mathrm{~m} 3$

Volume for 20 irrigations $=4536 * 20=90720 \mathrm{~m} 3$

This volume can now be compared with that required under drip system which is only $10524 \mathrm{~m}^{3}$ i.e. about $12 \%$. 
Table.1. Basic Data Sheet for Preparation of Irrigation Schedule

\begin{tabular}{|c|c|c|}
\hline Sr. No. & Particulars & Detail \\
\hline A & Farm Specifics & \\
\hline 1 & Name of Farmer & \\
\hline 2 & Educational Level & \\
\hline 3 & Village & \\
\hline 4 & Tehsil & \\
\hline 5 & District & \\
\hline B & Crop Data & \\
\hline 1 & Name of Crop & \\
\hline 2 & Crop Growth Duration & \\
\hline 3 & Total Area of The Crop & \\
\hline 4 & Date of Sowing & \\
\hline 5 & Expected Date of Harvesting & \\
\hline 6 & R-R Distance & \\
\hline 7 & P-P Distance & \\
\hline 8 & $\mathrm{ET}_{0}$ Values for the Period of Crop Duration & \\
\hline 9 & Crop Growth Coefficient Curve & \\
\hline 10 & Tentative Values of Canopy Factor & \\
\hline C & System Particulars & \\
\hline 1 & Type of System (Drip or Sprinkler) & \\
\hline 2 & System Flow Rate/Discharge & \\
\hline 3 & System Efficiency & \\
\hline 4 & Moisture Status of the Root Zone Before Sowing & \\
\hline 5 & Depth of Ground Water Table & \\
\hline 6 & Value of Effective Rainfall on its Occurrence & \\
\hline 7 & Number of Zones & \\
\hline 8 & Area of Each Zone & \\
\hline 9 & L-L Distance & \\
\hline 10 & E-E Distance & \\
\hline 11 & Discharge/Flow Rate of Each Emitter & \\
\hline 12 & Number of Emitters in one Zone & \\
\hline 13 & Value of Daily CWR & \\
\hline 14 & Irrigation Cycle & \\
\hline 15 & Storage Tank Capacity & \\
\hline
\end{tabular}


Table. 2. Reference Evapotranspiration of All Districts of Punjab

\begin{tabular}{|c|c|c|c|c|c|c|c|c|c|c|c|c|c|}
\hline & \multicolumn{13}{|c|}{$\mathrm{ET}_{0}(\mathrm{~mm}) / \mathrm{Day}$} \\
\hline \multirow{2}{*}{$\begin{array}{l}\text { Sr. } \\
\text { No. }\end{array}$} & \multirow{2}{*}{ Districts } & \multicolumn{12}{|c|}{ Months } \\
\hline & & Jan & Feb & $\begin{array}{c}\mathrm{Ma} \\
\mathrm{r}\end{array}$ & Apr & $\begin{array}{c}\text { Ma } \\
y\end{array}$ & Jun & Jul & Aug & Sep & Oct & Nov & Dec \\
\hline 1 & Attock & 1.3 & 2.1 & 3.4 & 4.7 & 5.9 & 6.1 & 4.8 & 4.5 & 4.2 & 3.0 & 1.7 & 1.2 \\
\hline 2 & Bahawalnaga & 1.9 & 2.9 & 4.3 & 6.0 & 7.6 & 8.3 & 6.4 & 6.1 & 5.5 & 4.2 & 2.6 & 1.8 \\
\hline 3 & Bahawalpur & 1.8 & 2.8 & 4.1 & 5.5 & 6.8 & 7.7 & 6.2 & 6.0 & 5.3 & 3.9 & 2.5 & 1.7 \\
\hline 4 & Bhakkar & 1.5 & 2.4 & 3.9 & 5.2 & 6.7 & 7.4 & 6.1 & 5.6 & 5.0 & 3.5 & 2.0 & 1.5 \\
\hline 5 & Chakwal & 1.3 & 2.1 & 3.4 & 4.7 & 5.9 & 6.1 & 4.8 & 4.5 & 4.2 & 3.0 & 1.7 & 1.2 \\
\hline 6 & Chiniot & 1.4 & 2.3 & 3.6 & 5.0 & 6.4 & 6.8 & 5.5 & 5.0 & 4.7 & 3.3 & 1.9 & 1.4 \\
\hline 7 & Dera Ghazi & 1.5 & 2.5 & 4.1 & 5.2 & 6.4 & 7.6 & 6.2 & 5.9 & 5.2 & 3.5 & 2.0 & 1.5 \\
\hline 8 & Faisalabad & 1.4 & 2.2 & 3.6 & 4.9 & 6.2 & 6.5 & 5.3 & 4.8 & 4.6 & 3.3 & 1.9 & 1.3 \\
\hline 9 & Gujranwala & 1.3 & 2.1 & 3.4 & 4.7 & 6.0 & 6.2 & 5.0 & 4.6 & 4.3 & 3.1 & 1.8 & 1.2 \\
\hline 10 & Gujrat & 1.5 & 2.3 & 3.7 & 5.2 & 6.6 & 6.9 & 5.4 & 4.6 & 4.8 & 3.9 & 2.6 & 1.7 \\
\hline 11 & Hafizabad & 1.4 & 2.3 & 3.6 & 5.0 & 6.4 & 6.8 & 5.5 & 5.0 & 4.7 & 3.3 & 1.9 & 1.4 \\
\hline 12 & Jhang & 1.4 & 2.3 & 3.6 & 5.0 & 6.4 & 6.8 & 5.5 & 5.0 & 4.7 & 3.3 & 1.9 & 1.4 \\
\hline 13 & Jehlum & 1.3 & 2.1 & 3.4 & 4.7 & 5.9 & 6.1 & 4.8 & 4.5 & 4.2 & 3.0 & 1.7 & 1.2 \\
\hline 14 & Kasur & 1.3 & 2.1 & 3.5 & 4.8 & 6.0 & 6.3 & 4.9 & 4.6 & 4.3 & 3.1 & 1.8 & 1.2 \\
\hline 15 & Khanewal & 1.5 & 2.4 & 3.9 & 5.1 & 6.4 & 7.1 & 5.8 & 5.4 & 4.9 & 3.4 & 1.9 & 1.4 \\
\hline 16 & Khushab & 1.5 & 2.4 & 3.9 & 5.2 & 6.7 & 7.4 & 6.1 & 5.6 & 5.0 & 3.5 & 2.0 & 1.5 \\
\hline 17 & Lahore & 1.3 & 2.3 & 3.6 & 5.3 & 6.2 & 6.2 & 5.4 & 4.8 & 4.4 & 3.2 & 2.1 & 1.4 \\
\hline 18 & Layyah & 1.5 & 2.4 & 3.9 & 5.2 & 6.7 & 7.4 & 6.1 & 5.6 & 5.0 & 3.5 & 2.0 & 1.5 \\
\hline 19 & Lodhran & 1.5 & 2.5 & 4.1 & 5.2 & 6.4 & 7.6 & 6.2 & 5.9 & 5.2 & 3.5 & 2.0 & 1.5 \\
\hline 20 & Mandi & 1.5 & 2.3 & 3.7 & 5.2 & 6.6 & 6.9 & 5.4 & 4.6 & 4.8 & 3.9 & 2.6 & 1.7 \\
\hline 21 & Mianwali & 1.4 & 1.9 & 2.9 & 4.3 & 5.7 & 6.2 & 5.8 & 5.1 & 4.7 & 3.4 & 2.1 & 1.4 \\
\hline 22 & Multan & 1.4 & 2.1 & 3.2 & 4.8 & 6.1 & 7.0 & 6.1 & 5.9 & 5.1 & 3.4 & 2.1 & 1.4 \\
\hline 23 & Muzaffargarh & 1.5 & 2.5 & 4.1 & 5.2 & 6.4 & 7.6 & 6.2 & 5.9 & 5.2 & 3.5 & 2.0 & 1.5 \\
\hline 24 & Norowal & 1.3 & 2.1 & 3.4 & 4.7 & 5.9 & 6.1 & 4.8 & 4.5 & 4.2 & 3.0 & 1.7 & 1.2 \\
\hline 25 & Nankana & 1.3 & 2.1 & 3.4 & 4.7 & 6.0 & 6.2 & 5.0 & 4.6 & 4.3 & 3.1 & 1.8 & 1.2 \\
\hline 26 & Okara & 1.5 & 2.4 & 3.9 & 5.1 & 6.4 & 7.1 & 5.8 & 5.4 & 4.9 & 3.4 & 1.9 & 1.4 \\
\hline 27 & Pakpattan & 1.5 & 2.5 & 4.1 & 5.2 & 6.4 & 7.6 & 6.2 & 5.9 & 5.2 & 3.5 & 2.0 & 1.5 \\
\hline 28 & R. Y. Khan & 1.9 & 2.9 & 4.3 & 5.7 & 7.0 & 7.8 & 6.4 & 6.1 & 5.3 & 4.0 & 2.5 & 1.8 \\
\hline 29 & Rajanpur & 1.5 & 2.5 & 4.1 & 5.2 & 6.4 & 7.6 & 6.2 & 5.9 & 5.2 & 3.5 & 2.0 & 1.5 \\
\hline 30 & Rawalpindi & 1.3 & 2.1 & 3.4 & 4.7 & 5.9 & 6.1 & 4.8 & 4.5 & 4.2 & 3.0 & 1.7 & 1.2 \\
\hline 31 & Sahiwal & 1.5 & 2.4 & 3.9 & 5.1 & 6.4 & 7.1 & 5.8 & 5.4 & 4.9 & 3.4 & 1.9 & 1.4 \\
\hline 32 & Sargodha & 1.5 & 2.4 & 3.8 & 5.3 & 6.8 & 7.2 & 5.8 & 5.0 & 4.9 & 3.8 & 2.5 & 1.6 \\
\hline 33 & Sheikhupura & 1.3 & 2.1 & 3.4 & 4.7 & 6.0 & 6.2 & 5.0 & 4.6 & 4.3 & 3.1 & 1.8 & 1.2 \\
\hline 34 & Sialkot & 1.3 & 2.1 & 3.4 & 4.7 & 5.9 & 6.1 & 4.8 & 4.5 & 4.2 & 3.0 & 1.7 & 1.2 \\
\hline 35 & T T Singh & 1.4 & 2.2 & 3.6 & 4.9 & 6.2 & 6.5 & 5.3 & 4.8 & 4.6 & 3.3 & 1.9 & 1.3 \\
\hline 36 & Vehari & 1.5 & 2.5 & 4.1 & 5.2 & 6.4 & 7.6 & 6.2 & 5.9 & 5.2 & 3.5 & 2.0 & 1.5 \\
\hline
\end{tabular}


Table. 3. Duration of Growth Stages of Agronomic Crops \& Corresponding Kc Values

\begin{tabular}{|c|c|c|c|c|c|c|c|c|c|c|c|c|}
\hline $\begin{array}{l}\dot{0} \\
\dot{1} \\
\dot{\omega}\end{array}$ & 은 & 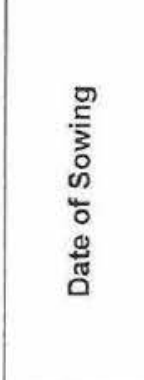 & 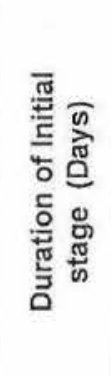 & 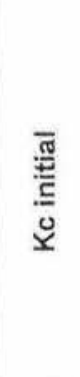 & 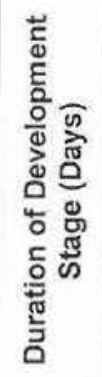 & 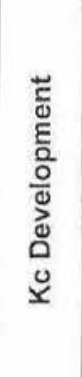 & 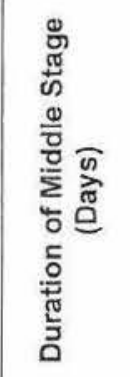 & 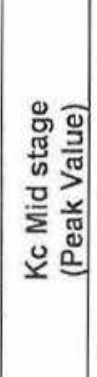 & 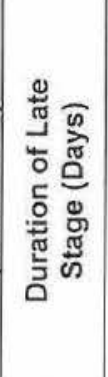 & 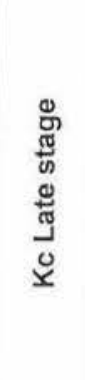 & 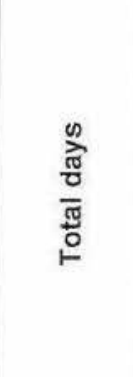 & 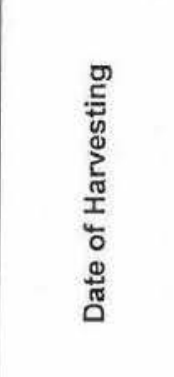 \\
\hline 1 & Barley & Nov & 15 & 0.3 & 25 & 0.9 & 50 & 1.15 & 30 & 1.0 & 120 & April \\
\hline 2 & Beans & Jun & 15 & 0.4 & 25 & 0.7 & 35 & 1.05 & 20 & 0.95 & 95 & Sep \& Oct \\
\hline 3 & Canola & Oct & 25 & 0.35 & 45 & 0.7 & 70 & 1.15 & 40 & 1.0 & 180 & Mar \& April \\
\hline 4 & Castor Beans & March & 25 & 0.35 & 40 & 0.8 & 65 & 1.15 & 50 & 1.1 & 180 & Sep \& Oct \\
\hline 5 & Cotton & April & 30 & 0.5 & 50 & 0.8 & 60 & 1.25 & 55 & 0.9 & 195 & Nov \& Dec \\
\hline 6 & Grams & Oct & 20 & 0.4 & 30 & 0.9 & 45 & 1.05 & 20 & 1 & 115 & Feb \& Mar \\
\hline 7 & Groundnut & March & 25 & 0.5 & 35 & 0.8 & 45 & 1.15 & 25 & 0.85 & 130 & July \& Aug \\
\hline 8 & Maize & Feb/Jul & 20 & 0.5 & 30 & 0.85 & 40 & 1.2 & $20 / 25$ & 0.9 & 115 & May \& Nov \\
\hline 9 & Millets & Jun/Jul & 15 & 0.4 & 25 & 0.7 & 40 & 1.0 & 25 & 0.9 & 105 & October \\
\hline 10 & Rapeseed & Oct & 25 & 0.35 & 45 & 0.7 & 70 & 1.15 & 40 & 1.0 & 180 & Mar \& Apr \\
\hline 11 & Rice & Jun/Jul & 30 & 1.15 & 30 & 1.15 & 60 & 1.2 & 30 & 1.05 & 150 & Nov \& Dec \\
\hline 12 & Safflower & Nov & 25 & 0.5 & 40 & 0.8 & 65 & 1.0 & 30 & 0.8 & 160 & April \\
\hline 13 & Sesame & Jun/Jul & 15 & 0.35 & 25 & 1 & 50 & 1.1 & 20 & 1.0 & 110 & Oct \& Nov \\
\hline 14 & Sorghum & July & 20 & 0.4 & 35 & 0.7 & 40 & 1.1 & 30 & 0.8 & 125 & Nov \& Dec \\
\hline 15 & Soybeans & Feb July & $20 / 20$ & 0.4 & $25 / 35$ & 0.8 & $50 / 60$ & 1.15 & $15 / 20$ & 0.8 & $110 / 130$ & June \& Nov \\
\hline 16 & Sugarcane & Feb Sep & $30 / 35$ & 0.5 & $60 / 65$ & 0.9 & $180 / 200$ & 1.3 & $60 / 90$ & 0.8 & $330 / 390$ & Dec \& Jan \\
\hline 17 & Sugar Beets & Oct & 30 & 0.5 & 45 & 60 & 90 & 1.2 & 15 & 0.9 & 180 & April \\
\hline 18 & Sunflower & Jan Feb & 25 & 0.4 & 35 & 0.7 & 45 & 1.2 & 25 & 0.8 & 130 & June \\
\hline 19 & Sweet Corn & Feb July & 20 & 0.3 & 30 & 0.7 & 40 & 1.15 & 20 & 1.1 & 110 & June \& Nov \\
\hline 20 & Mustard & Oct & 25 & 0.3 & 45 & 0.7 & 70 & 1.0 & 40 & 1.1 & 180 & April \\
\hline 21 & Tobacco & Oct & 30 & 0.4 & 40 & 0.8 & 50 & 1.2 & 30 & 0.9 & 150 & Mar \& April \\
\hline 22 & Wheat & Nov & 15 & 0.4 & 25 & 0.8 & 50 & 1.2 & 30 & 0.7 & 120 & April \\
\hline
\end{tabular}


Table. 4 Duration of Growth Stages and Kc Values of Vegetables Crops

\begin{tabular}{|c|c|c|c|c|c|c|c|c|c|c|c|c|}
\hline \multirow{2}{*}{$\begin{array}{l}\text { Sr. } \\
\text { No }\end{array}$} & \multirow{2}{*}{ Crop } & \multirow{2}{*}{$\begin{array}{l}\text { Date of } \\
\text { Sowing }\end{array}$} & \multicolumn{2}{|c|}{ Initial Stage } & \multicolumn{2}{|c|}{$\begin{array}{l}\text { Development } \\
\text { Stage }\end{array}$} & \multicolumn{2}{|c|}{$\begin{array}{c}\text { Mid Stage } \\
\text { (Peak Value) }\end{array}$} & \multicolumn{2}{|c|}{ Late Stage } & \multirow{2}{*}{$\begin{array}{l}\text { Total } \\
\text { Days }\end{array}$} & \multirow{2}{*}{$\begin{array}{c}\text { Date of } \\
\text { Harvesting }\end{array}$} \\
\hline & & & Duration & Kc & Duration & $\mathrm{Kc}$ & Duration & $\mathrm{Kc}$ & Duration & $\mathrm{Kc}$ & & \\
\hline 1 & Ash gourd & Oct \&Feb & 15 & 0.6 & 25 & 0.9 & 50 & 1 & 30 & 1 & 120 & March \\
\hline 2 & Bitter gourd & Mar Jun & 30 & 0.6 & 40 & 0.9 & 50 & 1 & 30 & 1 & 150 & Sep \& Oct \\
\hline 3 & Beans (green) & Oct & 15 & 0.4 & 25 & 0.7 & 25 & 0.95 & 10 & 0.95 & 75 & Jan \\
\hline 4 & Beans dry & Mar & 15 & 0.4 & 25 & 0.8 & 35 & 1.15 & 20 & 0.7 & 95 & July \\
\hline 5 & Bringle & Apr & 30 & 0.6 & 50 & 0.9 & 60 & 1.05 & 40 & 0.9 & 180 & Nov \& Dec \\
\hline 6 & Cabbage & Oct & 30 & 0.4 & 40 & 0.9 & 65 & 1.05 & 30 & 1 & 165 & Feb \& Mar \\
\hline 7 & Capsicum & Mar & 25 & 0.5 & 35 & 0.8 & 45 & 1.05 & 25 & 0.9 & 130 & July \& Aug \\
\hline 8 & Carrot & Oct & 15 & 0.7 & 25 & 0.9 & 40 & 1.05 & 20 & 0.95 & 100 & January \\
\hline 9 & Cauliflower & Aug & 15 & 0.7 & 25 & 0.9 & 40 & 1.05 & 20 & 0.95 & 100 & December \\
\hline 10 & Chilies & Feb & 30 & 0.3 & 40 & 0.5 & 70 & 0.75 & 30 & 1 & 170 & August \\
\hline 11 & Cucumber & Feb /Mar & 15 & 0.6 & 20 & 0.9 & 30 & 1 & 15 & 0.9 & 80 & May/Jun \\
\hline 12 & Egg Plant & Nov & 20 & 0.6 & 30 & 0.8 & 55 & 1.05 & 25 & 0.9 & 130 & April \\
\hline 13 & Garlic & Sep/Oct & 30 & 0.7 & 40 & 0.9 & 70 & 1 & 30 & 0.7 & 170 & March/April \\
\hline \multirow{2}{*}{14} & \multirow{2}{*}{ Ladyfinger } & Feb / Mar & 15 & 0.7 & 20 & 0.8 & 40 & 1 & 15 & 0.9 & 90 & May/June \\
\hline & & Jun & 15 & 0.7 & 20 & 0.8 & 40 & 1 & 15 & 0.9 & 90 & September \\
\hline 15 & Lettuce & Feb/Sep & 25 & 0.7 & 35 & 0.8 & 30 & 1 & 10 & 0.95 & 100 & Dec \& Jan \\
\hline 16 & Muskmelon & Mar & 20 & 0.5 & 25 & 0.75 & 40 & 1.05 & 15 & 0.75 & 100 & July/August \\
\hline 17 & Onion dry & Oct & 15 & 0.5 & 25 & 0.75 & 70 & 1.05 & 30 & 0.75 & 140 & April \\
\hline 18 & Onion (Gr) & Oct & 15 & 0.5 & 25 & 0.75 & 60 & 1 & - & - & 100 & February \\
\hline 19 & Peas (Gr) & Sep/Oct & 20 & 0.5 & 25 & 0.85 & 35 & 1.15 & - & - & 80 & Dec/Jan \\
\hline 20 & Peas seed & Sep/ Oct & 20 & 0.5 & 25 & 0.85 & 35 & 1.15 & 20 & 0.3 & 100 & Jan/Feb \\
\hline 21 & Potato & Sep/Oct & 25 & 0.5 & 30 & 0.85 & 35 & 1.15 & 30 & 0.75 & 1.20 & Dec/Jan \\
\hline 22 & Pumpkin & Feb & 20 & 0.6 & 30 & 0.9 & 30 & 1 & 20 & 0.8 & 100 & June/July \\
\hline 23 & Radish & July Nov & 10 & 0.7 & 15 & 0.8 & 20 & 0.9 & 5 & 0.85 & 50 & Sep to Jan \\
\hline 24 & Spinach & Mar June & 20 & 0.7 & 30 & 0.85 & 40 & 1 & 10 & 0.95 & 100 & July to Oct \\
\hline 25 & Squash & Feb June & 25 & 0.5 & 35 & 0.75 & 25 & 0.95 & 15 & 0.75 & 100 & June \& Oct \\
\hline 26 & Tomato & Sep/ Oct & 30 & 0.6 & 40 & 0.9 & 40 & 1.15 & 25 & 0.8 & 135 & Feb/March \\
\hline 27 & Turnip & Sep Nov & 10 & 0.5 & 20 & 0.85 & 25 & 1.1 & 5 & 0.95 & 60 & Nov to Jan \\
\hline 28 & Watermelon & Feb/Mar & 15 & 0.4 & 30 & 0.7 & 30 & 1 & 25 & 0.75 & 100 & June/July \\
\hline
\end{tabular}


Table. 5. Duration of Growth Stages and Kc Values of Fruit Crops

\begin{tabular}{|c|c|c|c|c|c|c|c|c|c|}
\hline $\begin{array}{l}\text { Sr. } \\
\text { No. }\end{array}$ & Fruit Name & $\begin{array}{l}\text { Initial } \\
\text { Stage }\end{array}$ & $\begin{array}{c}\text { Kc } \\
\text { Initial }\end{array}$ & $\begin{array}{l}\text { Dev. } \\
\text { Stage }\end{array}$ & $\begin{array}{c}\text { Kc } \\
\text { Dev. }\end{array}$ & $\begin{array}{c}\text { Mid } \\
\text { Stage }\end{array}$ & Kc Mid & $\begin{array}{l}\text { Late } \\
\text { Stage }\end{array}$ & Kc Late \\
\hline 1 & Almond & & 0.4 & & & & 0.9 & & 0.65 \\
\hline 2 & Apple & & 0.45 & & & & 0.95 & & 0.7 \\
\hline 3 & Apricot & & 0.45 & & & & 0.9 & & 0.65 \\
\hline 4 & Banana & & 0.5 & & & & 1.1 & & 1 \\
\hline 5 & Ber & & & & & & 1.1 & & \\
\hline 6 & Berries & & 0.3 & & & & 1.05 & & 0.5 \\
\hline 7 & Chiku & & & & & & 1.1 & & \\
\hline 8 & Citrus & & 0.5 & & & & $0.65-0.8$ & & $0.6-0.85$ \\
\hline 9 & Cherries & & 0.45 & & & & 0.95 & & 0.7 \\
\hline 10 & Date Palm & & 0.9 & & & & 0.95 & & 0.95 \\
\hline 11 & Fig & & & & & & 1 & & \\
\hline 12 & Grapes & & 0.3 & & & & 0.95 & & 0.45 \\
\hline 13 & Guava & & & & & & 1 & & \\
\hline 14 & Lychee & & & & & & 1.05 & & \\
\hline 15 & Mango & & & & & & 0.65 & & \\
\hline 16 & Mulberry & & 0.4 & & 0.7 & & 1 & & 1 \\
\hline 17 & Olives & & 0.6 & & 0.65 & & 0.7 & & 0.7 \\
\hline 18 & Peaches & & 0.45 & & & & 0.9 & & 0.65 \\
\hline 19 & Pears & & 0.45 & & & & 0.95 & & 0.7 \\
\hline 20 & Plum & & 0.45 & & & & 1.15 & & 0.65 \\
\hline 21 & Pomegranate & & 0.5 & & 0.7 & & 0.75 & & 0.75 \\
\hline 22 & Strawberry & & & & & & 0.85 & & \\
\hline
\end{tabular}




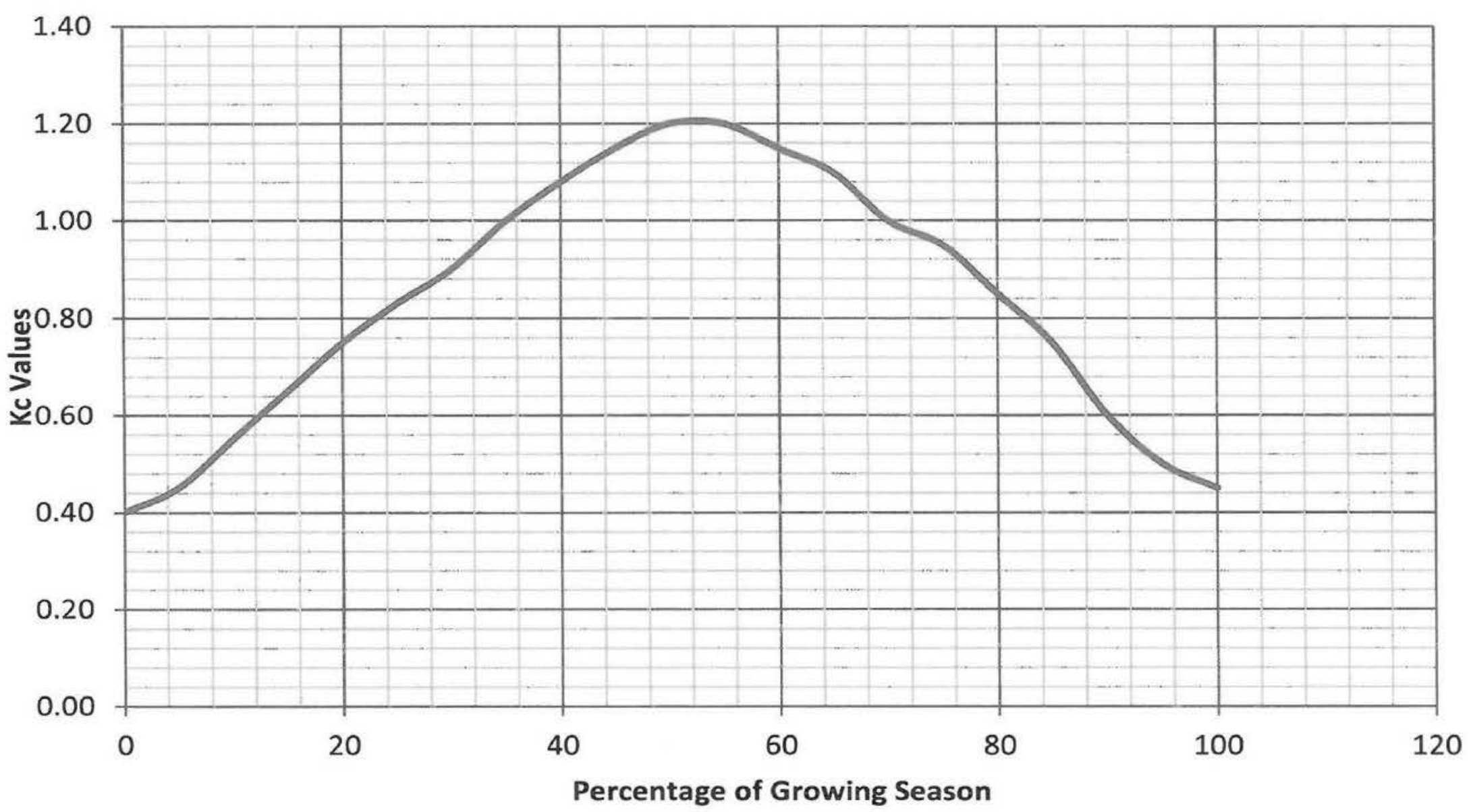

Figure - 1 Crop Growth Stage Coefficient (Kc) Curve for Cotton 


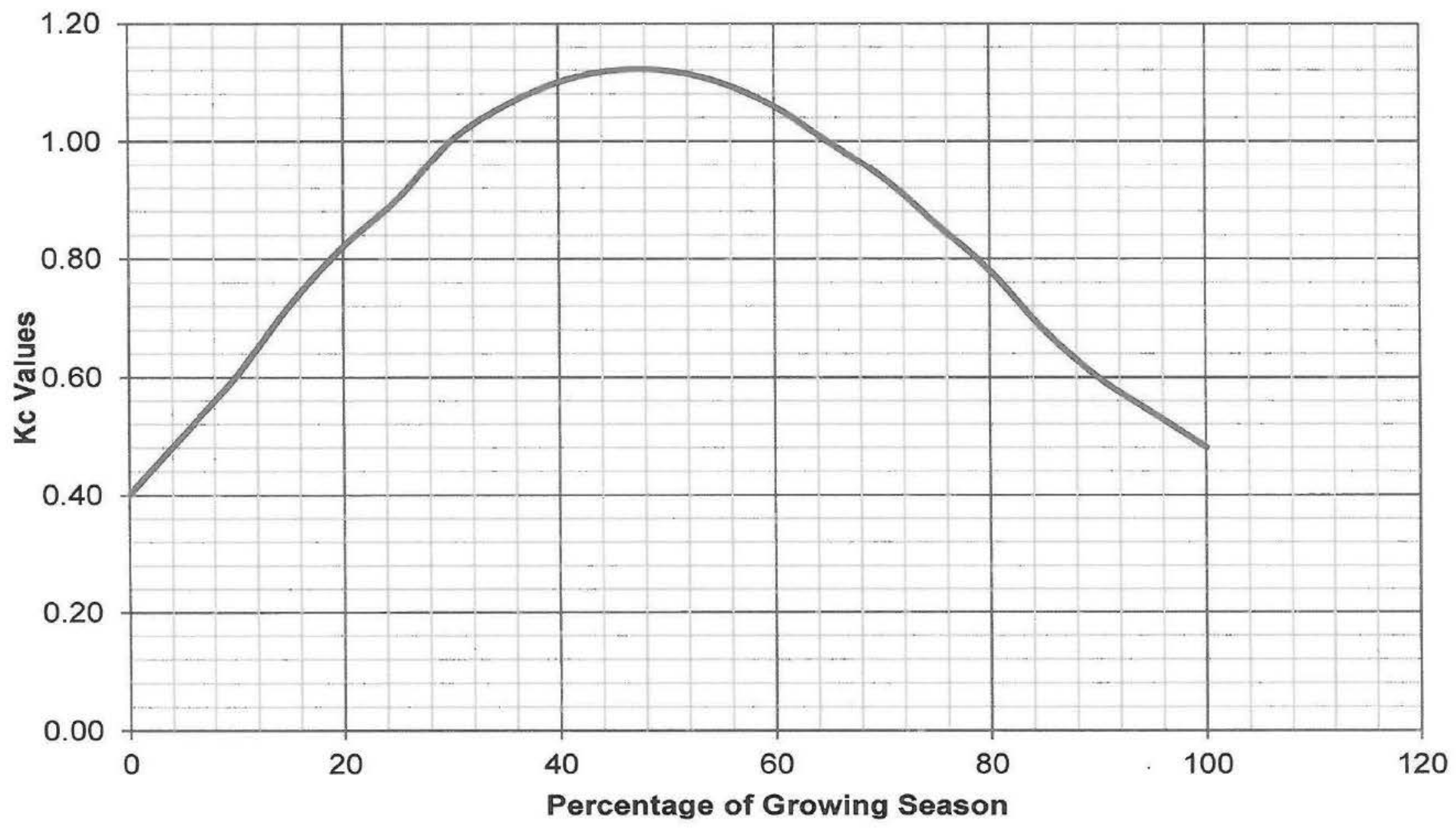

Figure - 3 Crop Growth Stage Coefficient (Kc) Curve for Sugarcane 


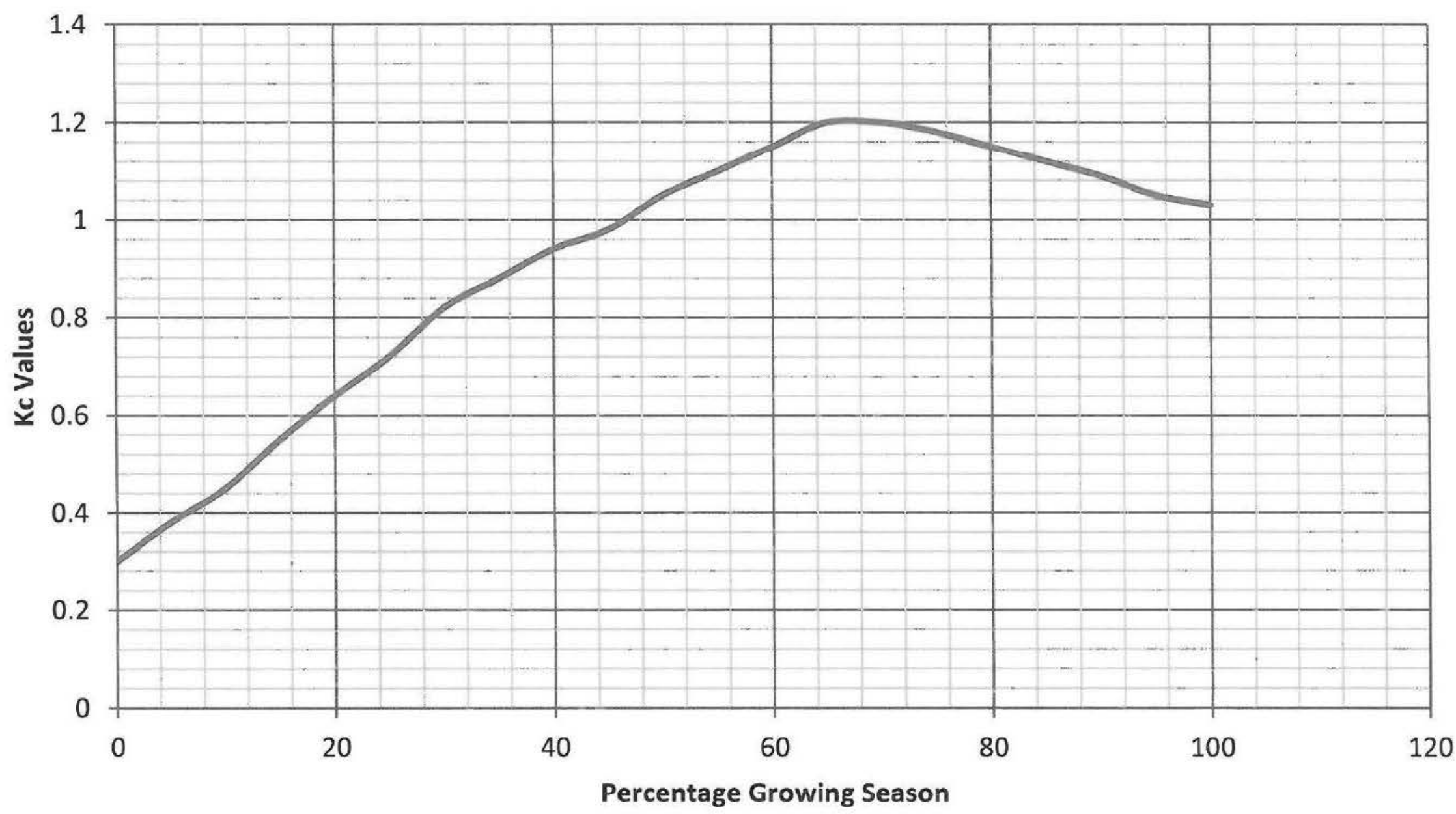

Figure - 2 Crop Growth Stage Coefficient (Kc) Curve for Maize 


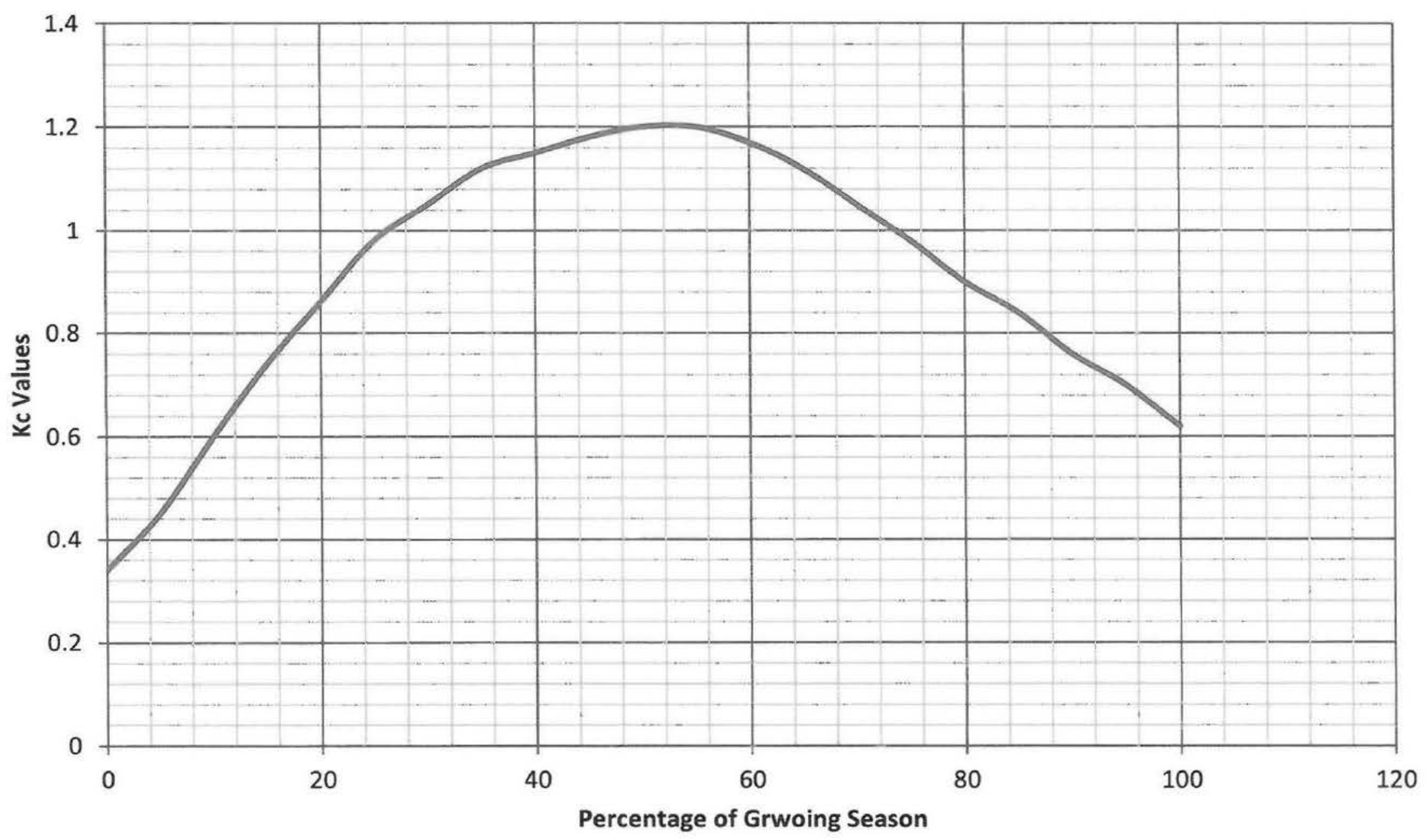

Figure - 4 Crop Growth Stage Coefficient (Kc) Curve for Wheat 


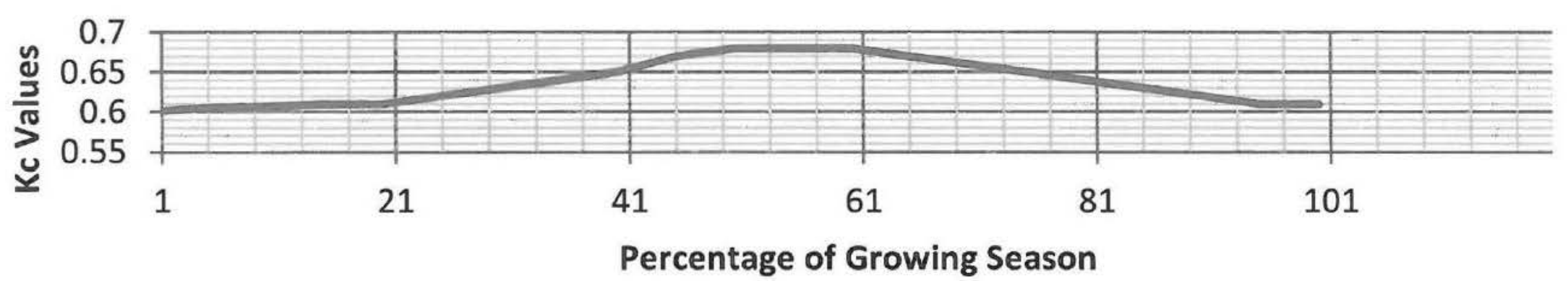

Figure - 5 Crop Growth Stage Coefficient (Kc) Curve for Citrus 


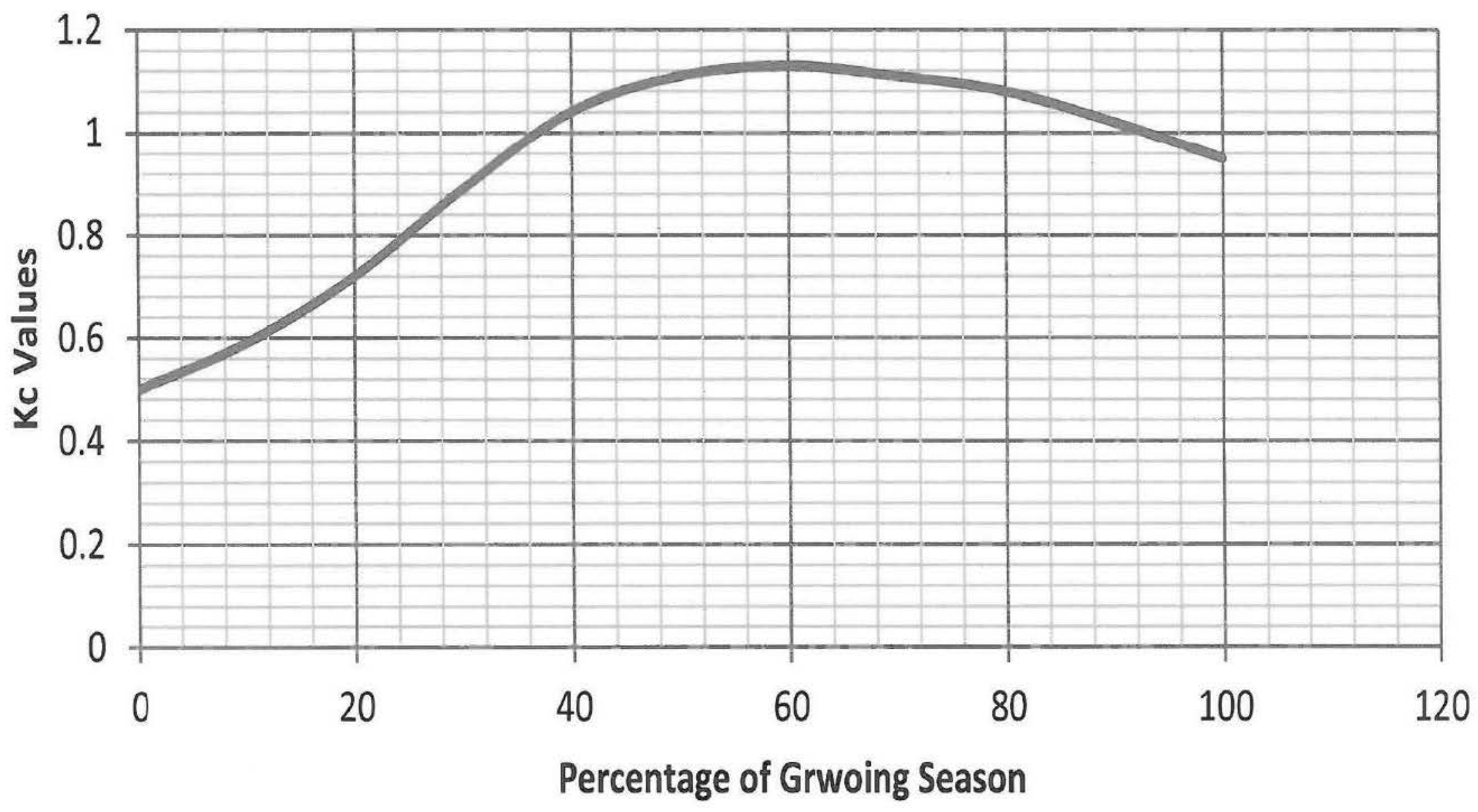

Figure -6 Crop Growth Stage Coefficient (Kc) Curve for Peas 
Table. 6. Sample Sheet for Preparation of Irrigation Schedule

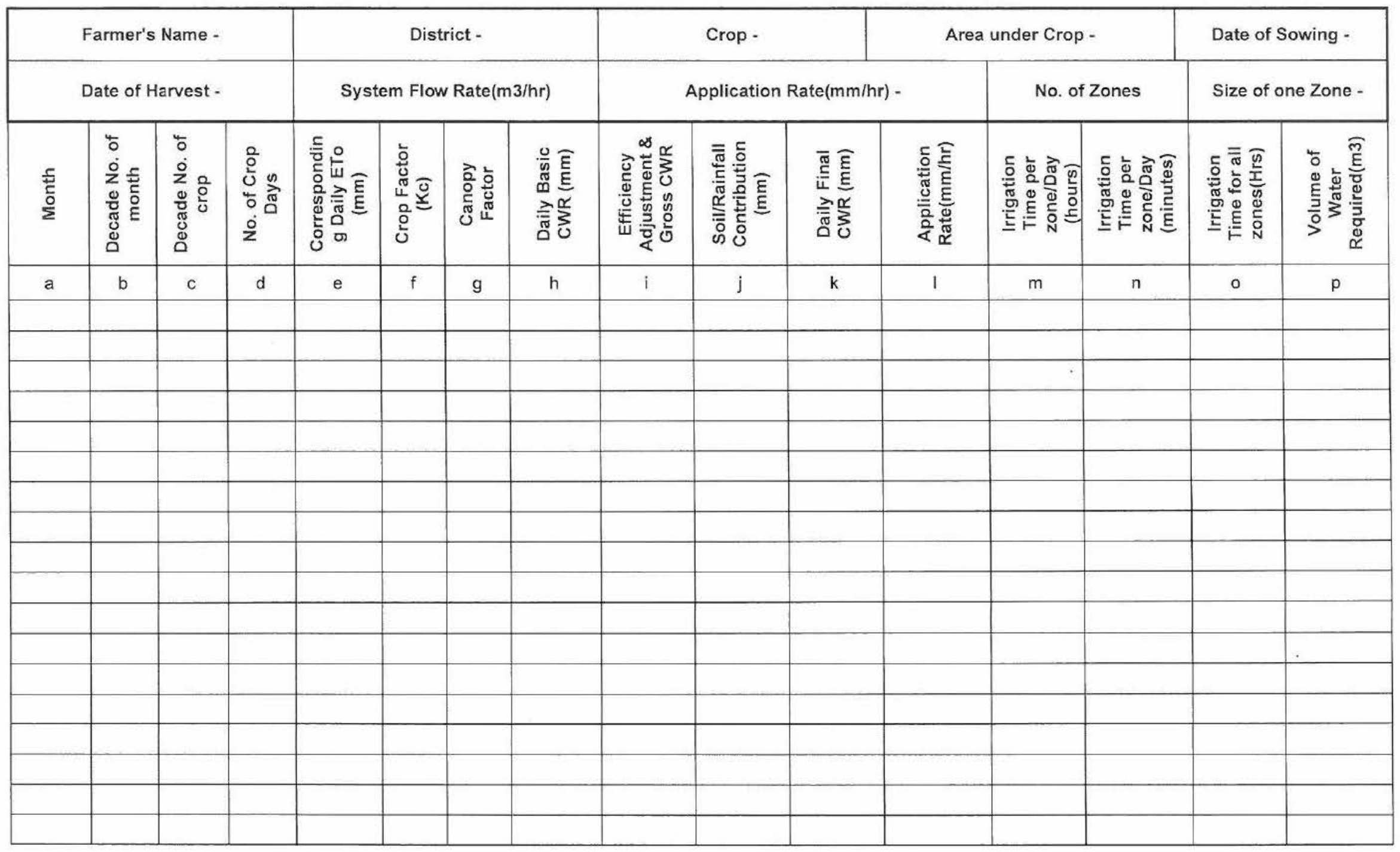


Table. 7. Irrigation Schedule for Cotton Crop

\begin{tabular}{|c|c|c|c|c|c|c|c|c|c|c|c|c|c|c|c|}
\hline \multirow{2}{*}{\multicolumn{4}{|c|}{$\begin{array}{l}\text { Farmer's Name - Rao Atif Ali } \\
\text { Date of Harvest - } 22.10 .12\end{array}$}} & \multirow{2}{*}{\multicolumn{4}{|c|}{$\begin{array}{l}\text { District - Muzaffar Garh } \\
\text { System Flow Rate(m3/hr) - } 49\end{array}$}} & \multicolumn{2}{|c|}{ Crop - Cotton } & \multicolumn{3}{|c|}{ Area under Crop - 14 Acres } & \multicolumn{3}{|c|}{ Date of Sowing - 26.4 .12} \\
\hline & & & & & & & & \multicolumn{4}{|c|}{ Application Rate $(\mathrm{mm} / \mathrm{hr})-5.33$} & \multicolumn{2}{|c|}{ No. of Zones - 7} & \multicolumn{2}{|c|}{$\begin{array}{l}\text { Size of one Zone - } 2 \\
\text { acres }\end{array}$} \\
\hline$\frac{5}{\stackrel{5}{L}}$ & 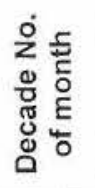 & 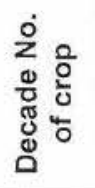 & 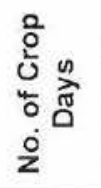 & 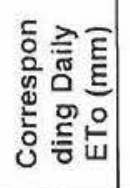 & 음 & 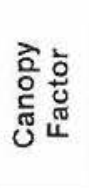 & 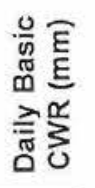 & 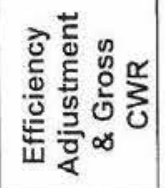 & 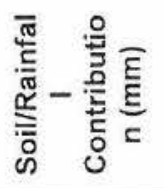 & 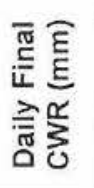 & 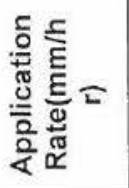 & 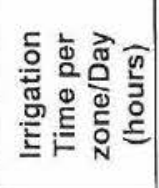 & 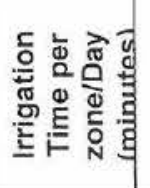 & 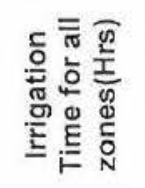 & 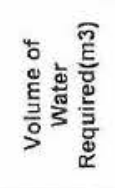 \\
\hline a & $b$ & c & $d$ & e & $f$ & g & $\mathrm{h}$ & $\mathrm{i}$ & j & $k$ & 1 & $\mathrm{~m}$ & $n$ & o & $p$ \\
\hline Apr & 3 & 1 & 5 & 5.2 & 0.34 & 0.4 & 0.71 & 0.79 & 0.00 & 0.79 & 5.33 & 0.15 & 9 & 1.0 & 253 \\
\hline \multirow{3}{*}{ May } & 1 & 2 & 10 & 6.4 & 0.4 & 0.7 & 1.79 & 1.99 & 0.00 & 1.99 & 5.33 & 0.37 & 22 & 2.6 & 1281 \\
\hline & 2 & 3 & 10 & 6.4 & 0.5 & 0.8 & 2.56 & 2.84 & 0.00 & 2.84 & 5.33 & 0.53 & 32 & 3.7 & 1830 \\
\hline & 3 & 4 & 11 & 6.4 & 0.62 & 0.9 & 3.57 & 3.97 & 0.00 & 3.97 & 5.33 & 0.74 & 45 & 5.2 & 2809 \\
\hline \multirow{3}{*}{ Jun } & 1 & 5 & 10 & 7.6 & 0.74 & 1 & 5.62 & 6.25 & 0.00 & 6.25 & 5.33 & 1.17 & 70 & 8.2 & 4021 \\
\hline & 2 & 6 & 10 & 7.6 & 0.82 & 1 & 6.23 & 6.92 & 0.00 & 6.92 & 5.33 & 1.30 & 78 & 9.1 & 4456 \\
\hline & 3 & 7 & 10 & 7.6 & 0.92 & 1 & 6.99 & 7.77 & 0.00 & 7.77 & 5.33 & 1.46 & 87 & 10.2 & 4999 \\
\hline \multirow{3}{*}{ Jul } & 1 & 8 & 10 & 6.2 & 0.98 & 1 & 6.08 & 6.75 & 0.00 & 6.75 & 5.33 & 1.27 & 76 & 8.9 & 4345 \\
\hline & 2 & 9 & 10 & 6.2 & 1 & 1 & 6.20 & 6.89 & 0.00 & 6.89 & 5.33 & 1.29 & 78 & 9.0 & 4433 \\
\hline & 3 & 10 & 11 & 6.2 & 0.98 & 1 & 6.08 & 6.75 & 0.00 & 6.75 & 5.33 & 1.27 & 76 & 8.9 & 4779 \\
\hline \multirow{3}{*}{ Aug } & 1 & 11 & 10 & 5.9 & 0.95 & 1.1 & 6.17 & 6.85 & 0.00 & 6.85 & 5.33 & 1.29 & 77 & 9.0 & 4409 \\
\hline & 2 & 12 & 10 & 5.9 & 0.9 & 1.1 & 5.84 & 6.49 & 0.00 & 6.49 & 5.33 & 1.22 & 73 & 8.5 & 4176 \\
\hline & 3 & 13 & 11 & 5.9 & 0.8 & 1.1 & 5.19 & 5.77 & 0.00 & 5.77 & 5.33 & 1.08 & 65 & 7.6 & 4084 \\
\hline \multirow{3}{*}{ Sep } & 1 & 14 & 10 & 5.2 & 0.72 & 1 & 3.74 & 4.16 & 0.00 & 4.16 & 5.33 & 0.78 & 47 & 5.5 & 2677 \\
\hline & 2 & 15 & 10 & 5.2 & 0.65 & 1 & 3.38 & 3.76 & 0.00 & 3.76 & 5.33 & 0.70 & 42 & 4.9 & 2417 \\
\hline & 3 & 16 & 10 & 5.2 & 0.56 & 1 & 2.91 & 3.24 & 0.00 & 3.24 & 5.33 & 0.61 & 36 & 4.2 & 2082 \\
\hline \multirow{3}{*}{ Oct } & 1 & 17 & 10 & 3.5 & 0.48 & 1 & 1.68 & 1.87 & 0.00 & 1.87 & 5.33 & 0.35 & 21 & 2.5 & 1201 \\
\hline & 2 & 18 & 10 & 3.5 & 0.44 & 1 & 1.54 & 1.71 & 0.00 & 1.71 & 5.33 & 0.32 & 19 & 2.2 & 1101 \\
\hline & 3 & 19 & 2 & 4.5 & 0.42 & 1 & 1.89 & 2.10 & 0.00 & 2.10 & 5.33 & 0.39 & 24 & 2.8 & 270 \\
\hline \multicolumn{15}{|c|}{ Total } & 55625 \\
\hline
\end{tabular}


Table. 8. Irrigation Schedule for Sugarcane Crop

\begin{tabular}{|c|c|c|c|c|c|c|c|c|c|c|c|c|c|c|c|}
\hline \multicolumn{4}{|c|}{ Farmer Name: Muhammad Azam } & \multicolumn{2}{|c|}{ District: MB Din } & \multicolumn{3}{|c|}{ Crop: Sugarcane } & \multicolumn{3}{|c|}{ Area under Crop: 9 Acre } & \multirow{2}{*}{\multicolumn{4}{|c|}{$\begin{array}{c}\text { Date of Sowing: } 13.9 .12 \\
\text { Size of one Zone }=1.50 \text { acre or } 0.6 \mathrm{Ha}\end{array}$}} \\
\hline \multicolumn{3}{|c|}{ Date of Harvest: 1.11 .13} & \multirow{2}{*}{ 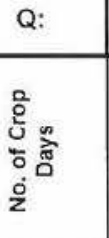 } & \multirow{2}{*}{ 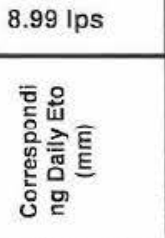 } & \multicolumn{2}{|c|}{$32.4 \mathrm{~m} 3 / \mathrm{h}$} & \multicolumn{2}{|c|}{ Application Rate $(\mathrm{mm} / \mathrm{hr})$ : } & \multirow{2}{*}{ 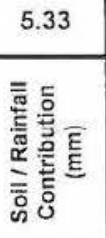 } & \multicolumn{2}{|c|}{ No. of Zones: 6} & & & & \\
\hline $\begin{array}{l}\text { 吉 } \\
\text { 号 } \\
\text { ¿ }\end{array}$ & 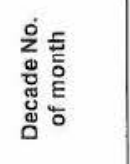 & 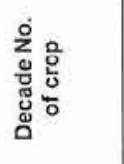 & & & 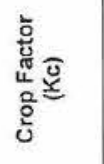 & 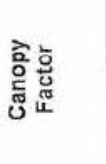 & 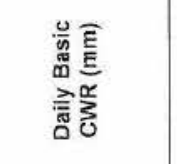 & 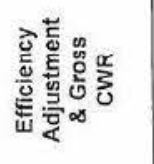 & & 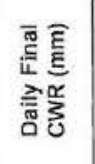 & 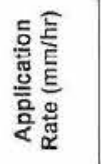 & 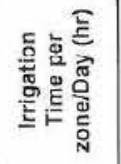 & 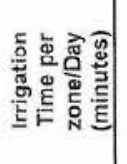 & 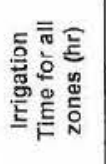 & 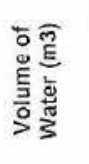 \\
\hline a & b & c & d & e & f & $\mathrm{g}$ & h & $\mathrm{i}$ & j & k & 1 & $\mathrm{~m}$ & $n$ & 0 & $p$ \\
\hline \multirow[t]{2}{*}{ Sep } & 2 & 1 & 7 & 4.8 & 0.45 & 0.3 & 0.65 & 0.7 & 0 & 0.7 & 5.33 & 0.14 & 8 & 0.81 & 184 \\
\hline & 3 & 2 & 10 & 4.8 & 0.54 & 0.4 & 1.04 & 1.2 & 0 & 1.2 & 5.33 & 0.22 & 13 & 1.30 & 420 \\
\hline \multirow{3}{*}{ Oct } & 1 & 3 & 10 & 3.9 & 0.6 & 0.4 & 0.94 & 1.0 & 0 & 1.0 & 5.33 & 0.20 & 12 & 1.17 & 379 \\
\hline & 2 & 4 & 10 & 3.9 & 0.64 & 0.4 & 1.00 & 1.1 & 0 & 1.1 & 5.33 & 0.21 & 12 & 1.25 & 405 \\
\hline & 3 & 5 & 11 & 3.9 & 0.7 & 0.5 & 1.37 & 1.5 & 0 & 1.5 & 5.33 & 0.28 & 17 & 1.71 & 608 \\
\hline \multirow[t]{3}{*}{ Nov } & 1 & 6 & 10 & 2.6 & 0.78 & 0.5 & 1.01 & 1.1 & 0 & 1.1 & 5.33 & 0.21 & 13 & 1.27 & 411 \\
\hline & 2 & 7 & 10 & 2.6 & 0.82 & 0.5 & 1.07 & 1.2 & 0 & 1.2 & 5.33 & 0.22 & 13 & 1.33 & 432 \\
\hline & 3 & 8 & 10 & 2.6 & 0.88 & 0.6 & 1.37 & 1.5 & 0 & 1.5 & 5.33 & 0.29 & 17 & 1.72 & 556 \\
\hline \multirow{3}{*}{ Dec } & 1 & 9 & 10 & 1.7 & 0.94 & 0.7 & 1.12 & 1.2 & 0 & 1.2 & 5.33 & 0.23 & 14 & 1.40 & 453 \\
\hline & 2 & 10 & 10 & 1.7 & 1 & 0.7 & 1.19 & 1.3 & 0 & 1.3 & 5.33 & 0.25 & 15 & 1.49 & 482 \\
\hline & 3 & 11 & 11 & 1.7 & 1.04 & 0.7 & 1.24 & 1.4 & 0 & 1.4 & 5.33 & 0.26 & 15 & 1.55 & 552 \\
\hline \multirow{3}{*}{ Jan } & 1 & 12. & 10 & 1.5 & 1.08 & 0.7 & 1.13 & 1.3 & 0 & 1.3 & 5.33 & 0.24 & 14 & 1.42 & 460 \\
\hline & 2 & 13 & 10 & 1.5 & 1.1 & 0.7 & 1.16 & 1.3 & 0 & 1.3 & 5.33 & 0.24 & 14 & 1.44 & 468 \\
\hline & 3 & 14 & 11 & 1.5 & 1.14 & 0.75 & 1.28 & 1.4 & 0 & 1.4 & 5.33 & 0.27 & 16 & 1.60 & 572 \\
\hline \multirow{3}{*}{ Feb } & 1 & 15 & 10 & 2.3 & 1.18 & 0.75 & 2.04 & 2.3 & 0 & 2.3 & 5.33 & 0.42 & 25 & 2.55 & 825 \\
\hline & 2 & 16 & 10 & 2.3 & 1.22 & 0.8 & 2.24 & 2.5 & 0 & 2.5 & 5.33 & 0.47 & 28 & 2.81 & 910 \\
\hline & 3 & 17 & 8 & 2.3 & 1.26 & 0.85 & 2.46 & 2.7 & 0 & 2.7 & 5.33 & 0.51 & 31 & 3.08 & 799 \\
\hline \multirow{3}{*}{ Mar } & 1 & 18 & 10 & 3.7 & 1.28 & 0.9 & 4.26 & 4.7 & 0 & 4.7 & 5.33 & 0.89 & 53 & 5.33 & 1727 \\
\hline & 2 & 19 & 10 & 3.7 & 1.3 & 0.95 & 4.57 & 5.1 & 0 & 5.1 & 5.33 & 0.95 & 57 & 5.72 & 1852 \\
\hline & 3 & 20 & 11 & 3.7 & 1.3 & 1 & 4.81 & 5.3 & 0 & 5.3 & 5.33 & 1.00 & 60 & 6.02 & 2144 \\
\hline \multirow{3}{*}{ Apr } & 1 & 21 & 10 & 5.2 & 1.3 & 1 & 6.76 & 7.5 & 0 & 7.5 & 5.33 & 1.41 & 85 & 8.46 & 2740 \\
\hline & 2 & 22 & 10 & 5.2 & 1.28 & 1 & 6.66 & 7.4 & 0 & 7.4 & 5.33 & 1.39 & 83 & 8.33 & 2697 \\
\hline & 3 & 23 & 10 & 5.2 & 1.24 & 1 & 6.45 & 7.2 & 0 & 7.2 & 5.33 & 1.34 & 81 & 8.07 & 2613 \\
\hline
\end{tabular}

Continued.......... 


\begin{tabular}{|c|c|c|c|c|c|c|c|c|c|c|c|c|c|c|c|}
\hline \multicolumn{4}{|c|}{ Farmer Name: Muhammad Azam } & \multicolumn{2}{|c|}{ District: MB Din } & \multicolumn{3}{|c|}{ Crop: Sugarcane } & \multicolumn{3}{|c|}{ Area under Crop: 9 Acre } & \multirow{2}{*}{\multicolumn{4}{|c|}{ 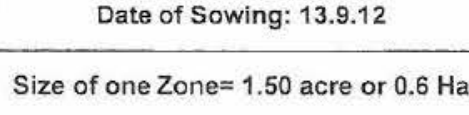 }} \\
\hline \multicolumn{3}{|c|}{ Date of Harvest: 1.11 .13} & \multirow{2}{*}{ 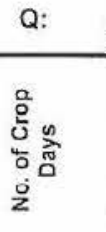 } & \multirow{2}{*}{ 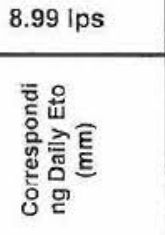 } & \multicolumn{2}{|c|}{$32.4 \mathrm{~m} 3 / \mathrm{h}$} & \multicolumn{2}{|c|}{ Application Rate $(\mathrm{mm} / \mathrm{hr})$ : } & \multirow{2}{*}{ 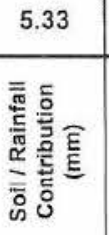 } & \multicolumn{2}{|c|}{ No. of Zones: 6} & & & & \\
\hline $\begin{array}{l}\frac{5}{\underline{E}} \\
\text { है }\end{array}$ & 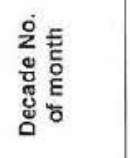 & 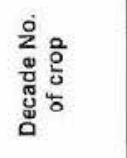 & & & 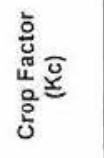 & 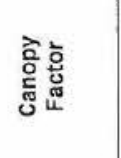 & 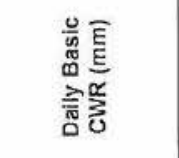 & 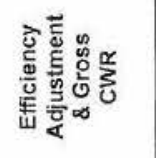 & & 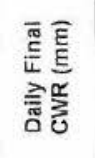 & 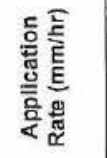 & 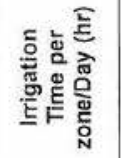 & 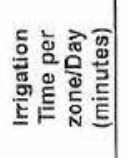 & 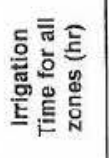 & 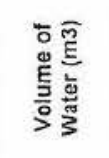 \\
\hline a & b & c & d & e & f & g & $\mathrm{h}$ & $\mathrm{i}$ & j & k & 1 & $m$ & $n$ & 0 & $p$ \\
\hline \multirow{3}{*}{ May } & 1 & 24 & 10 & 6.6 & 1.2 & 1 & 7.92 & 8.8 & 0 & 8.8 & 5.33 & 1.65 & 99 & 9.91 & 3210 \\
\hline & 2 & 25 & 10 & 6.6 & 1.18 & 1 & 7.79 & 8.7 & 0 & 8.7 & 5.33 & 1.62 & 97 & 9.74 & 3156 \\
\hline & 3 & 26 & 11 & 6.6 & 1.16 & 1 & 7.66 & 8.5 & 0 & 8.5 & 5.33 & 1.60 & 96 & 9.58 & 3413 \\
\hline \multirow[t]{3}{*}{ Jun } & 1 & 27 & 10 & 6.9 & 1.12 & 1 & 7.73 & 8.6 & 0 & 8.6 & 5.33 & 1.61 & 97 & 9.67 & 3132 \\
\hline & 2 & 28 & 10 & 6.9 & 1.1 & 1 & 7.59 & 8.4 & 0 & 8.4 & 5.33 & 1.58 & 95 & 9.49 & 3076 \\
\hline & 3 & 29 & 10 & 6.9 & 1.06 & 1 & 7.31 & 8.1 & 0 & 8.1 & 5.33 & 1.52 & 91 & 9.15 & 2964 \\
\hline \multirow[t]{3}{*}{ Jul } & 1 & 30 & 10 & 5.4 & 1.04 & 1 & 5.62 & 6.2 & 0 & 6.2 & 5.33 & 1.17 & 70 & 7.02 & 2276 \\
\hline & 2 & 31 & 10 & 5.4 & 1.02 & 1 & 5.51 & 6.1 & 0 & 6.1 & 5.33 & 1.15 & 69 & 6.89 & 2232 \\
\hline & 3 & 32 & 11 & 5.4 & 0.96 & 1 & 5.18 & 5.8 & 0 & 5.8 & 5.33 & 1.08 & 65 & 6.48 & 2311 \\
\hline \multirow[t]{3}{*}{ Aug } & 1 & 33 & 10 & 4.8 & 0.92 & 1 & 4.42 & 4.9 & 0 & 4.9 & 5.33 & 0.92 & 55 & 5.52 & 1790 \\
\hline & 2 & 34 & 10 & 4.8 & 0.9 & 1 & 4.32 & 4.8 & 0 & 4.8 & 5.33 & 0.90 & 54 & 5.40 & 1751 \\
\hline & 3 & 35 & 11 & 4.8 & 0.88 & 1 & 4.22 & 4.7 & 0 & 4.7 & 5.33 & 0.88 & 53 & 5.28 & 1883 \\
\hline \multirow[t]{3}{*}{ Sep } & 1 & 36 & 10 & 4.6 & 0.85 & 1 & 3.91 & 4.3 & 0 & 4.3 & 5.33 & 0.82 & 49 & 4.89 & 1585 \\
\hline & 2 & 37 & 10 & 4.6 & 0.82 & 1 & 3.77 & 4.2 & 0 & 4.2 & 5.33 & 0.79 & 47 & 4.72 & 1529 \\
\hline & 3 & 38 & 10 & 4.6 & 0.8 & 1 & 3.68 & 4.1 & 0 & 4.1 & 5.33 & 0.77 & 46 & 4.60 & 1491 \\
\hline \multirow[t]{3}{*}{ Oct } & 1 & 39 & 10 & 3.9 & 0.78 & 1 & 3.04 & 3.4 & 0 & 3.4 & 5.33 & 0.63 & 38 & 3.80 & 1233 \\
\hline & 2 & 40 & 10 & 3.9 & 0.76 & 1 & 2.96 & 3.3 & 0 & 3.3 & 5.33 & 0.62 & 37 & 3.71 & 1201 \\
\hline & 3 & 41 & 11 & 3.9 & 0.75 & 1 & 2.93 & 3.3 & 0 & 3.3 & 5.33 & 0.61 & 37 & 3.66 & 1304 \\
\hline \multicolumn{3}{|c|}{ Total } & & & & & & & & & & & & & 62224 \\
\hline
\end{tabular}

Note: - Irrigation of Sugarcane Crop should be stopped about one month before harvest. 
Table. 9. Irrigation Schedule for Maize Crop

\begin{tabular}{|c|c|c|c|c|c|c|c|c|c|c|c|c|c|c|c|}
\hline \multicolumn{4}{|c|}{ Farmer Name: Farman Ali Basra } & \multicolumn{2}{|c|}{ District: Layyah } & \multicolumn{3}{|c|}{ Crop: Maize } & \multicolumn{3}{|c|}{ Area under Crop: 13.4 Acre } & \multicolumn{4}{|c|}{ Date of Sowing: 16.7 .12} \\
\hline \multicolumn{3}{|c|}{$\begin{array}{c}\text { Date of Harvest: } \\
24.10 .12\end{array}$} & \multirow{2}{*}{ 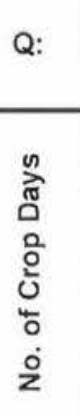 } & \multirow{2}{*}{ 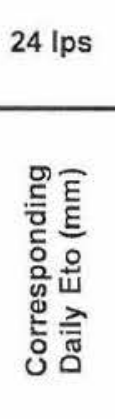 } & \multirow{2}{*}{$\begin{array}{c}86 \\
\mathrm{~m} 3 / \mathrm{h}\end{array}$} & \multicolumn{3}{|c|}{ Application Rate(mm/hr): } & \multirow{2}{*}{ 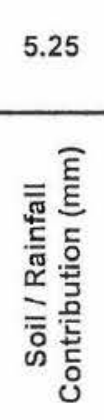 } & \multicolumn{2}{|c|}{ No. of Zones: 7} & \multicolumn{4}{|c|}{ Size of one Zone $=1.91$ acre } \\
\hline $\begin{array}{l}\text { I } \\
\text { 吉 } \\
\stackrel{0}{\Sigma}\end{array}$ & 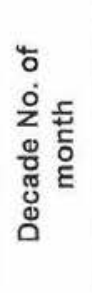 & 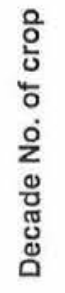 & & & & 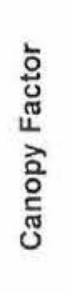 & 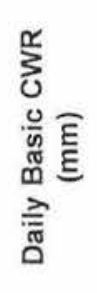 & 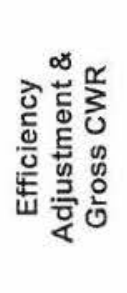 & & 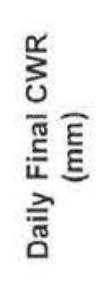 & 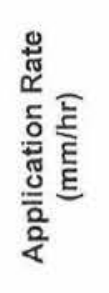 & 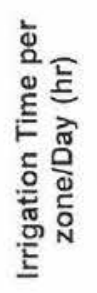 & 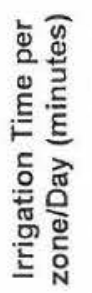 & 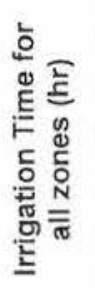 & 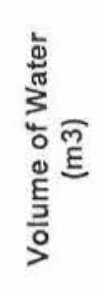 \\
\hline a & $b$ & c & d & e & $f$ & g & $\mathrm{h}$ & i & j & k & 1 & $\mathrm{~m}$ & n & $\circ$ & $\mathrm{p}$ \\
\hline \multirow[t]{2}{*}{ Jul } & 2 & 1 & 5 & 6.1 & 0.45 & 0.3 & 0.82 & 0.9 & 0 & 0.9 & 11.25 & 0.08 & 5 & 0.57 & 245 \\
\hline & 3 & 2 & 11 & 6.1 & 0.64 & 0.4 & 1.56 & 1.7 & 0 & 1.7 & 11.25 & 0.15 & 9 & 1.08 & 1021 \\
\hline \multirow[t]{3}{*}{ Aug } & 1 & 3 & 10 & 5.6 & 0.86 & 0.4 & 1.93 & 2.1 & 0 & 2.1 & 11.25 & 0.19 & 11 & 1.52 & 1309 \\
\hline & 2 & 4 & 10 & 5.6 & 1.05 & 0.4 & 2.35 & 2.6 & 0 & 2.6 & 11.25 & 0.23 & 14 & 1.86 & 1598 \\
\hline & 3 & 5 & 11 & 5.6 & 1.2 & 0.5 & 3.36 & 3.7 & 0 & 3.7 & 11.25 & 0.33 & 20 & 2.65 & 2511 \\
\hline \multirow[t]{3}{*}{ Sep } & 1 & 6 & 10 & 5 & 1.2 & 0.5 & 3.00 & 3.3 & 0 & 3.3 & 11.25 & 0.30 & 18 & 2.37 & 2039 \\
\hline & 2 & 7 & 10 & 5 & 1.2 & 0.5 & 3.00 & 3.3 & 0 & 3.3 & 11.25 & 0.30 & 18 & 2.37 & 2039 \\
\hline & 3 & 8 & 10 & 5 & 1.1 & 0.6 & 3.30 & 3.7 & 0 & 3.7 & 11.25 & 0.33 & 20 & 2.61 & 2242 \\
\hline \multirow[t]{3}{*}{ Oct } & 1 & 9 & 10 & 3.5 & 1.05 & 0.7 & 2.57 & 2.9 & 0 & 2.9 & 11.25 & 0.25 & 15 & 2.03 & 1748 \\
\hline & 2 & 10 & 10 & 3.5 & 1 & 0.7 & 2.45 & 2.7 & 0 & 2.7 & 11.25 & 0.24 & 15 & 1.94 & 1665 \\
\hline & 3 & 11 & 4 & 3.5 & 0.9 & 0.7 & 2.21 & 2.5 & 0 & 2.5 & 11.25 & 0.22 & 13 & 1.74 & 599 \\
\hline \multicolumn{15}{|c|}{ Total } & 17016 \\
\hline
\end{tabular}


Table. 10. Irrigation Schedule for Wheat

\begin{tabular}{|c|c|c|c|c|c|c|c|c|c|c|c|c|c|c|c|}
\hline \multicolumn{4}{|c|}{ Farmer Name- M. Riaz } & \multicolumn{2}{|c|}{ District- Gujrat } & \multicolumn{3}{|c|}{ Crop- Wheat } & \multicolumn{3}{|c|}{ Area under Crop- 4 Acre } & \multirow{2}{*}{\multicolumn{4}{|c|}{$\begin{array}{l}\text { Date of Sowing }-25.11 .13 \\
\text { Size of one Zone }=0.5 \text { acre }\end{array}$}} \\
\hline \multicolumn{3}{|c|}{ Date of Harvest- 10.4 .14} & \multicolumn{4}{|c|}{ System Flow Rate(m $3 / \mathrm{hr})=12.6$} & \multicolumn{3}{|c|}{ Application Rate $(\mathrm{mm} / \mathrm{hr})=6.29$} & \multicolumn{2}{|c|}{ No. of Zones $=8$} & & & & \\
\hline $\begin{array}{l}\text { 吉 } \\
\text { 号 }\end{array}$ & 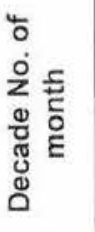 & 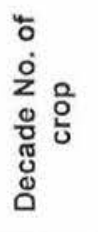 & 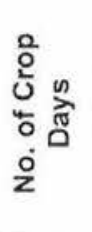 & 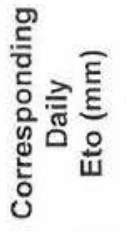 & $\begin{array}{l}\frac{5}{0} \\
\frac{0}{\pi} \\
\frac{0}{0} \\
\frac{0}{0} \\
\frac{0}{0}\end{array}$ & 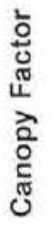 & 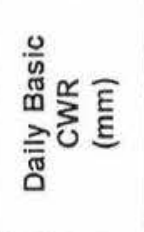 & 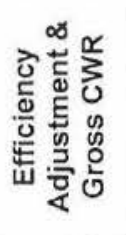 & 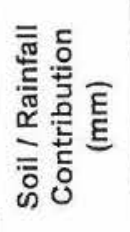 & 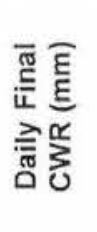 & 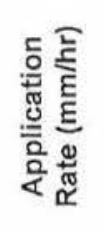 & 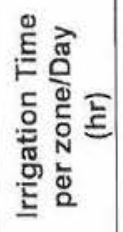 & 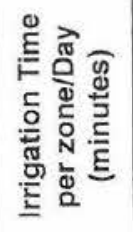 & 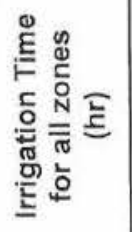 & 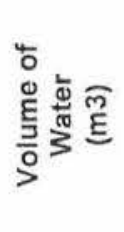 \\
\hline a & b & c & d & e & $f$ & g & h & i & j & k & 1 & $\mathrm{~m}$ & $n$ & o & $\mathrm{p}$ \\
\hline Nov & 3 & 1 & 6 & 2.6 & 0.4 & 1 & 1.04 & 1.5 & 0 & 1.5 & 6.29 & 0.24 & 14.2 & 1.9 & 142.9 \\
\hline \multirow{3}{*}{ Dec } & 1 & 2 & 10 & 1.7 & 0.4 & 1 & 0.68 & 1.0 & 0 & 1.0 & 6.29 & 0.15 & 9.3 & 1.2 & 155.7 \\
\hline & 2 & 3 & 10 & 1.7 & 0.8 & 1 & 1.36 & 1.9 & 0 & 1.9 & 6.29 & 0.31 & 18.5 & 2.5 & 311.4 \\
\hline & 3 & 4 & 11 & 1.7 & 0.8 & 1 & 1.36 & 1.9 & 0 & 1.9 & 6.29 & 0.31 & 18.5 & 2.5 & 342.5 \\
\hline \multirow{3}{*}{ Jan } & 1 & 5 & 10 & 1.5 & 0.9 & 1 & 1.35 & 1.9 & 0 & 1.9 & 6.29 & 0.31 & 18.4 & 2.5 & 309.1 \\
\hline & 2 & 6 & 10 & 1.5 & 1.2 & 1 & 1.8 & 2.6 & 0 & 2.6 & 6.29 & 0.41 & 24.5 & 3.3 & 412.1 \\
\hline & 3 & 7 & 11 & 1.5 & 1.2 & 1 & 1.8 & 2.6 & 0 & 2.6 & 6.29 & 0.41 & 24.5 & 3.3 & 453.3 \\
\hline \multirow{3}{*}{ Feb } & 1 & 8 & 10 & 2.3 & 1.2 & 1 & 2.76 & 3.9 & 0 & 3.9 & 6.29 & 0.63 & 37.6 & 5.0 & 631.9 \\
\hline & 2 & 9 & 10 & 2.3 & 1.2 & 1 & 2.76 & 3.9 & 0 & 3.9 & 6.29 & 0.63 & 37.6 & 5.0 & 631.9 \\
\hline & 3 & 10 & 8 & 2.3 & 1.2 & 1 & 2.76 & 3.9 & 0 & 3.9 & 6.29 & 0.63 & 37.6 & 5.0 & 505.5 \\
\hline \multirow{3}{*}{ Mar } & 1 & 11 & 10 & 3.7 & 0.9 & 1 & 3.33 & 4.8 & 0 & 4.8 & 6.29 & 0.76 & 45.4 & 6.1 & 762.4 \\
\hline & 2 & 12 & 10 & 3.7 & 0.7 & 1 & 2.59 & 3.7 & 0 & 3.7 & 6.29 & 0.59 & 35.3 & 4.7 & 592.9 \\
\hline & 3 & 13 & 10 & * & & & & & & & & & & & \\
\hline Apr & 1 & 14 & 10 & * & & & & & & & & & & & \\
\hline Total & & & 136 & & & & & & & & & & & & 5251.3 \\
\hline
\end{tabular}

* Avoid sprinkler irrigation during fluorescence 
Table 11. Irrigation Schedule for Citrus

\begin{tabular}{|c|c|c|c|c|c|c|c|c|c|c|c|c|c|c|c|}
\hline \multicolumn{3}{|c|}{ Farmer- Ch. Nisar Ahmad, M. Garh } & \multicolumn{3}{|c|}{ Crop- Citrus } & \multicolumn{3}{|c|}{ Sowing Date- 8.3 .12} & \multicolumn{3}{|c|}{ Harvesting Date- } & \multicolumn{2}{|c|}{ Area under crop-15 Acres } & & \\
\hline \multicolumn{3}{|c|}{ System Flow Rate-17.21 m $3 / \mathrm{H}$} & \multicolumn{3}{|c|}{ No. of Zones- 5} & \multicolumn{3}{|c|}{ App. Rate- $1.43 \mathrm{~mm} / \mathrm{H}$} & \multirow[b]{2}{*}{ 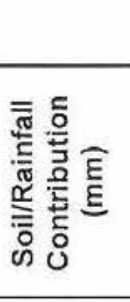 } & \multirow[b]{2}{*}{ 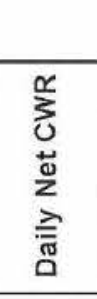 } & \multirow[b]{2}{*}{ 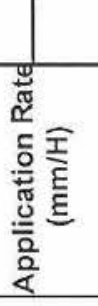 } & \multirow[b]{2}{*}{ 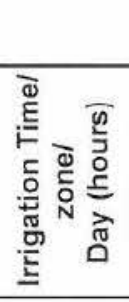 } & \multirow[b]{2}{*}{ 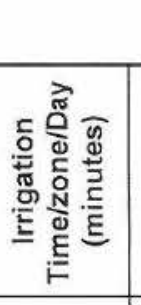 } & \multirow[b]{2}{*}{ 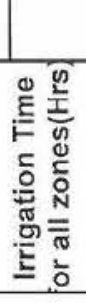 } & \multirow[b]{2}{*}{ 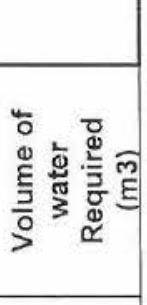 } \\
\hline 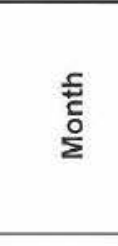 & 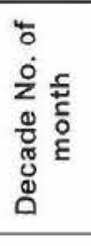 & 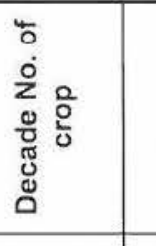 & $\begin{array}{l}\text { गे } \\
\text { ô } \\
0 \\
0 \\
0 \\
0 \\
0 \\
0 \\
2\end{array}$ & 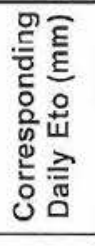 & 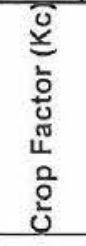 & 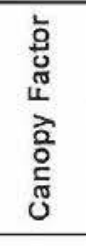 & 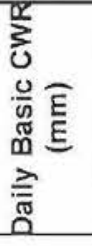 & 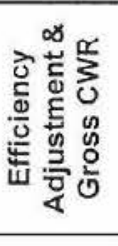 & & & & & & & \\
\hline$a$ & $b$ & c & d & e & f & g & h & $i$ & j & $k$ & I & $\mathrm{m}$ & $n$ & 0 & p \\
\hline Mar & & & 31 & 4.1 & 0.65 & 0.1 & 0.27 & 0.30 & 0.0 & 0.30 & 1.43 & 0.21 & 12 & 1.04 & 552 \\
\hline Apr & & & 30 & 5.2 & 0.65 & 0.12 & 0.41 & 0.45 & 0.0 & 0.45 & 1.43 & 0.32 & 19 & 1.58 & 814 \\
\hline May & & & 31 & 6.4 & 0.65 & 0.13 & 0.54 & 0.60 & 0.0 & 0.60 & 1.43 & 0.42 & 25 & 2.10 & 1121 \\
\hline Jun & & & 30 & 7.6 & 0.65 & 0.14 & 0.69 & 0.77 & 0.0 & 0.77 & 1.43 & 0.54 & 32 & 2.69 & 1387 \\
\hline Jul & & & 31 & 6.2 & 0.65 & 0.15 & 0.60 & 0.67 & 0.0 & 0.67 & 1.43 & 0.47 & 28 & 2.35 & 1253 \\
\hline Aug & & & 31 & 5.9 & 0.65 & 0.16 & 0.61 & 0.68 & 0.0 & 0.68 & 1.43 & 0.48 & 29 & 2.38 & 1272 \\
\hline Sep & & & 30 & 5.2 & 0.65 & 0.16 & 0.54 & 0.60 & 0.0 & 0.60 & 1.43 & 0.42 & 25 & 2.10 & 1085 \\
\hline Oct & & & 31 & 3.5 & 0.65 & 0.18 & 0.41 & 0.46 & 0.0 & 0.46 & 1.43 & 0.32 & 19 & 1.59 & 849 \\
\hline Nov & & & 30 & 2 & 0.65 & 0.2 & 0.26 & 0.29 & 0.0 & 0.29 & 1.43 & 0.20 & 12 & 1.01 & 522 \\
\hline Dec & & & 31 & 1.5 & 0.65 & 0.22 & 0.21 & 0.24 & 0.0 & 0.24 & 1.43 & 0.17 & 10 & 0.83 & 445 \\
\hline Jan & & & 31 & 1.5 & 0.65 & 0.23 & 0.22 & 0.25 & 0.0 & 0.25 & 1.43 & 0.17 & 10 & 0.87 & 465 \\
\hline Feb & & & 28 & 2.5 & 0.65 & 0.25 & 0.41 & 0.45 & 0.0 & 0.45 & 1.43 & 0.32 & 19 & 1.58 & 761 \\
\hline & & & & & & & & & & & & & & & 10524 \\
\hline
\end{tabular}


Table 12. Irrigation Schedule for Peas

\begin{tabular}{|c|c|c|c|c|c|c|c|c|c|c|c|c|c|c|c|}
\hline \multicolumn{4}{|c|}{ Farmer Name: Salah ud Din } & \multicolumn{2}{|c|}{ District: Pakpattan } & \multicolumn{3}{|c|}{ Crop: Peas (Green) } & \multicolumn{3}{|c|}{ Area under Crop: 5.76 Acres } & \multicolumn{4}{|c|}{ Date of Sowing: 1.10 .13} \\
\hline \multicolumn{3}{|c|}{ Date of Harvest: 30.12 .13} & \multirow{2}{*}{ 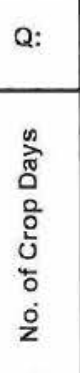 } & \multirow{2}{*}{ 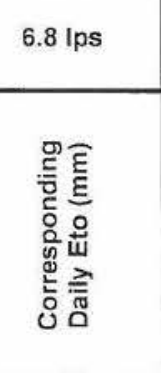 } & \multirow{2}{*}{$\begin{array}{c}24.4 \\
\mathrm{~m} 3 / \mathrm{h}\end{array}$} & \multirow[b]{2}{*}{ 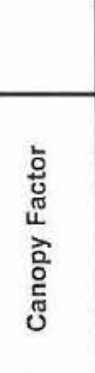 } & \multicolumn{2}{|c|}{$\begin{array}{c}\text { Application } \\
\text { Rate(mm/hr): }\end{array}$} & \multirow{2}{*}{ 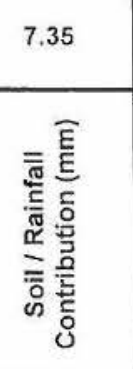 } & \multicolumn{2}{|c|}{ No. of Zones: 7} & \multicolumn{4}{|c|}{ Size of one Zone $=0.82$ acre or $0.332 \mathrm{Ha}$} \\
\hline $\begin{array}{l}\text { f } \\
\text { है } \\
\text { एँ }\end{array}$ & 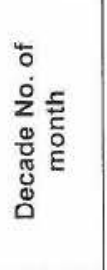 & 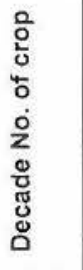 & & & & & 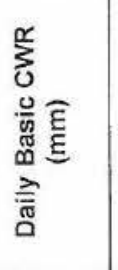 & 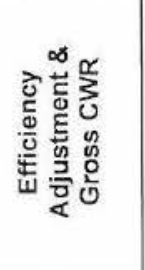 & & 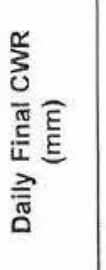 & 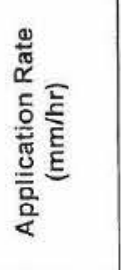 & 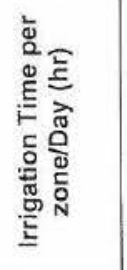 & 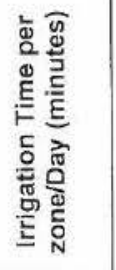 & 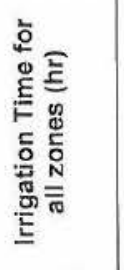 & 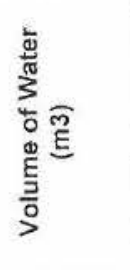 \\
\hline a & b & c & $d$ & e & $f$ & g & $\mathrm{h}$ & $\mathrm{i}$ & j & k & 1 & m & $\mathrm{n}$ & 0 & $\mathrm{p}$ \\
\hline \multirow[t]{3}{*}{ Oct } & 1 & 1 & 10 & 3.5 & 0.5 & 0.3 & 0.53 & 0.6 & 0 & 0.6 & 7.35 & 0.08 & 5 & 0.56 & 478 \\
\hline & 2 & 2 & 10 & 3.5 & 0.58 & 0.4 & 0.81 & 0.9 & 0 & 0.9 & 7.35 & 0.12 & 7 & 0.86 & 739 \\
\hline & 3 & 3 & 11 & 3.5 & 0.72 & 0.45 & 1.13 & 1.3 & 0 & 1.3 & 7.35 & 0.17 & 10 & 1.20 & 1135 \\
\hline \multirow[t]{3}{*}{ Nov } & 1 & 4 & 10 & 2 & 0.85 & 0.5 & 0.85 & 0.9 & 0 & 0.9 & 7.35 & 0.13 & 8 & 0.90 & 774 \\
\hline & 2 & 5 & 10 & 2 & 1.04 & 0.6 & 1.25 & 1.4 & 0 & 1.4 & 7.35 & 0.19 & 11 & 1.32 & 1136 \\
\hline & 3 & 6 & 10 & 2 & 1.12 & 0.7 & 1.57 & 1.7 & 0 & 1.7 & 7.35 & 0.24 & 14 & 1.66 & 1427 \\
\hline \multirow[t]{3}{*}{ Dec } & 1 & 7 & 10 & 1.5 & 1.15 & 0.8 & 1.38 & 1.5 & 0 & 1.5 & 7.35 & 0.21 & 13 & 1.46 & 1256 \\
\hline & 2. & 8 & 10 & 1.5 & 1.15 & 0.9 & 1.55 & 1.7 & 0 & 1.7 & 7.35 & 0.23 & 14 & 1.64 & 1413 \\
\hline & 3 & 9 & 10 & 1.5 & 1.15 & 1 & 1.73 & 1.9 & 0 & 1.9 & 7.35 & 0.26 & 16 & 1.83 & 1570 \\
\hline
\end{tabular}




\section{References:}

WILL BE FURNISHED ON REQUEST. 